Prepared in cooperation with the U.S. Fish and Wildlife Service

Summary of Wildlife-Related Research on the Coastal Plain of the Arctic National Wildlife Refuge, Alaska, 2002-17

Open-File Report 2018-1003 



\section{Summary of Wildlife-Related Research on the Coastal Plain of the Arctic National Wildlife Refuge, Alaska, 2002-17}

By John M. Pearce, Paul L. Flint, Todd C. Atwood, David C. Douglas, Layne G. Adams, Heather E. Johnson, Stephen M. Arthur, and Christopher J. Latty

Prepared in cooperation with the U.S. Fish and Wildlife Service

Open-File Report 2018-1003

U.S. Department of the Interior

U.S. Geological Survey 


\section{U.S. Department of the Interior RYAN K. ZINKE, Secretary}

\section{U.S. Geological Survey \\ William H. Werkheiser, Deputy Director \\ exercising the authority of the Director}

U.S. Geological Survey, Reston, Virginia: 2018

For more information on the USGS—-the Federal source for science about the Earth, its natural and living resources, natural hazards, and the environment-visit https://www.usgs.gov/ or call 1-888-ASK-USGS (1-888-275-8747).

For an overview of USGS information products, including maps, imagery, and publications, visit https://store.usgs.gov/.

Disclaimer: The findings and conclusions in this article are those of the author(s) and do not necessarily represent the views of the U.S. Fish and Wildlife Service.

Any use of trade, firm, or product names is for descriptive purposes only and does not imply endorsement by the U.S. Government.

Although this information product, for the most part, is in the public domain, it also may contain copyrighted materials as noted in the text. Permission to reproduce copyrighted items must be secured from the copyright owner.

Suggested citation:

Pearce, J.M., Flint, P.L., Atwood, T.C., Douglas, D.C., Adams, L.G., Johnson, H.E., Arthur, S.M., and Latty, C.J., 2018, Summary of wildlife-related research on the coastal plain of the Arctic National Wildlife Refuge, Alaska, 2002-17: U.S. Geological Survey Open-File Report 2018-1003, 27 p., https://doi.org/10.3133/ofr20181003.

ISSN 2331-1258 (online) 


\section{Contents}

Abstract ………

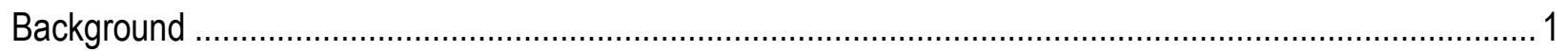

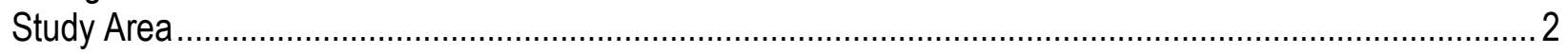

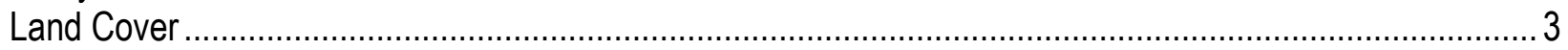

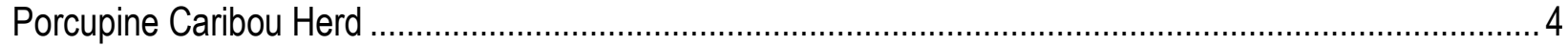

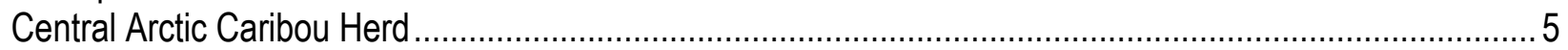

Forage Quantity and Quality ......................................................................................................

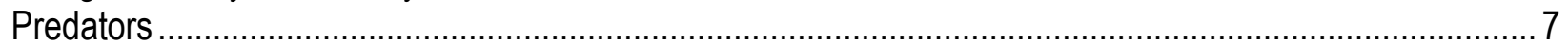

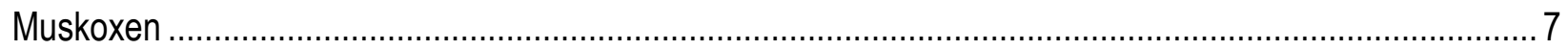

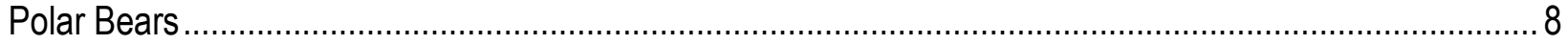

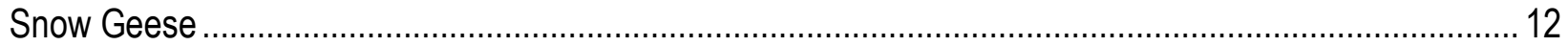

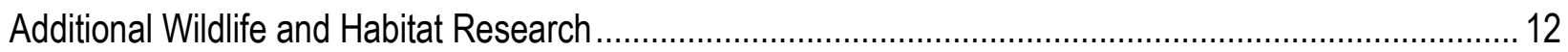

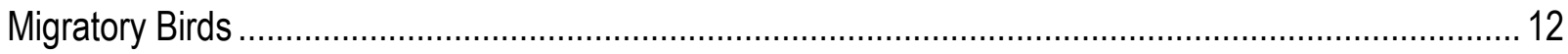

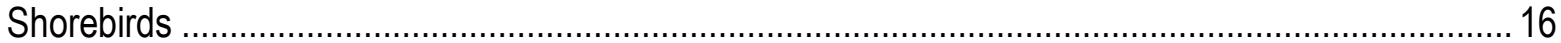

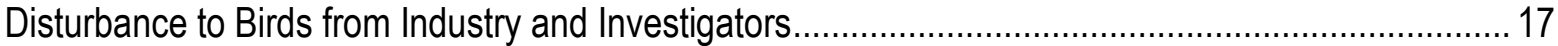

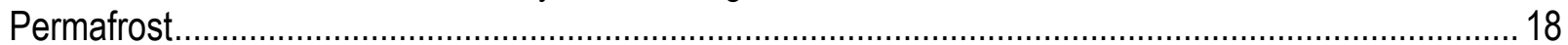

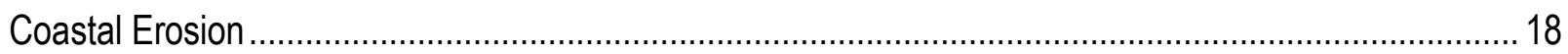

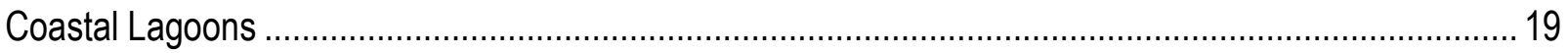

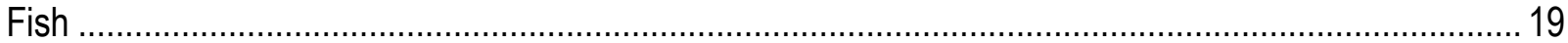

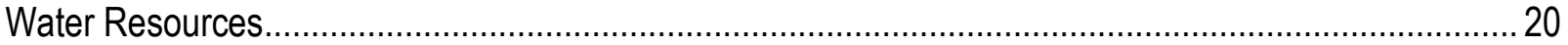

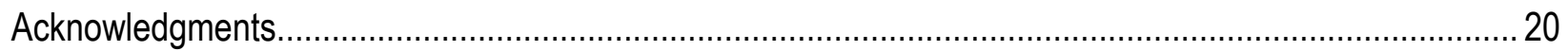

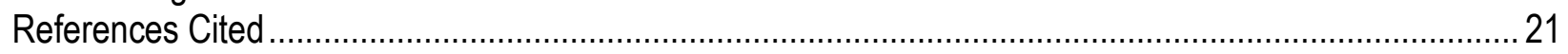

\section{Figures}

Figure 1. Map of 1002 Area showing approximate boundaries and main rivers, Arctic National Wildlife Refuge, Alaska

Figure 2. Map of approximate annual distributions of northern caribou herds in Alaska and Canada and approximate boundaries of the National Petroleum Reserve (NPR-A) and 1002 Area, Arctic National Wildlife Refuge (ANWR), Alaska

Figure 3. Map showing distribution of polar bears observed from 2010 to 2013 during autumn aerial surveys along the north coast, Alaska

Figure 4. Map showing polar bear maternal dens on land or fast ice discovered with very high frequency (VHF) or satellite telemetry along north coast, Alaska, 1982-2010

Figure 5. Map showing estimate of suitable polar bear maternal denning habitat within the approximate boundary of the 1002 Area, Arctic National Wildlife Refuge, Alaska.

\section{Tables}

Table 1. List of 57 fairly common, common, and abundant breeding and nonbreeding bird species for the coast, inland, and barrier island and lagoon regions of the 1002 Area of the Arctic National Wildlife Refuge, Alaska.

Table 2. Average number per year of the 17 most common bird species observed from 1999 to 2009 on coastal lagoon and barrier island aerial surveys within the 1002 Area of the Arctic National Wildlife Refuge, Alaska. 


\section{Conversion Factors}

U.S. customary units to International System of Units

\begin{tabular}{lcl}
\hline \multicolumn{1}{c}{ Multiply } & By & \multicolumn{1}{c}{ To obtain } \\
\hline foot $(\mathrm{ft})$ & Length & meter $(\mathrm{m})$ \\
mile $(\mathrm{mi})$ & 0.3048 & kilometer $(\mathrm{km})$ \\
\hline & 1.609 & square kilometer $\left(\mathrm{km}^{2}\right)$ \\
\hline square mile $\left(\mathrm{mi}^{2}\right)$ & Area & \\
\hline & 2.590 & cubic meter $\mathrm{per} \mathrm{second}\left(\mathrm{m}^{3} / \mathrm{s}\right)$ \\
\hline
\end{tabular}

International System of Units to U.S. customary units

\begin{tabular}{lcl}
\hline \multicolumn{1}{c}{ Multiply } & By & \multicolumn{1}{c}{ To obtain } \\
\hline meter $(\mathrm{m})$ & Length & foot $(\mathrm{ft})$ \\
meter $(\mathrm{m})$ & 3.281 & yard $(\mathrm{yd})$ \\
kilometer $(\mathrm{km})$ & 1.094 & mile $(\mathrm{mi})$ \\
kilometer $(\mathrm{km})$ & 0.6214 & mile, nautical $(\mathrm{nmi})$ \\
\hline & 0.5400 & \\
\hline square kilometer $\left(\mathrm{km}^{2}\right)$ & Area & square mile $\left(\mathrm{mi}^{2}\right)$ \\
\hline & 0.3861 & \\
\hline meter per year $(\mathrm{m} / \mathrm{yr})$ & Flow rate & foot per year $\mathrm{ft} / \mathrm{yr})$ \\
\hline
\end{tabular}

Temperature in degrees Celsius $\left({ }^{\circ} \mathrm{C}\right)$ may be converted to degrees Fahrenheit $\left({ }^{\circ} \mathrm{F}\right)$ as follows:

${ }^{\circ} \mathrm{F}=\left(1.8 \times{ }^{\circ} \mathrm{C}\right)+32$. 


\title{
Summary of Wildlife-Related Research on the Coastal Plain of the Arctic National Wildlife Refuge, Alaska, 2002-17
}

By John M. Pearce, ${ }^{1}$ Paul L. Flint, ${ }^{1}$ Todd C. Atwood, ${ }^{1}$ David C. Douglas,${ }^{1}$ Layne G. Adams, ${ }^{1}$ Heather E. Johnson, ${ }^{1}$ Stephen M. Arthur, ${ }^{2}$ and Christopher J. Latty ${ }^{2}$

\begin{abstract}
We summarize recent (2002-17) publicly available information from studies within the 1002 Area of the Arctic National Wildlife Refuge as well as terrestrial and coastal ecosystems elsewhere on the Arctic Coastal Plain that are relevant to the 1002 Area. This report provides an update on earlier research summaries on caribou (Rangifer tarandus), forage quality and quantity, polar bears (Ursus maritimus), muskoxen (Ovibos moschatus), and snow geese (Chen caerulescens). We also provide information on new research related to climate, migratory birds, permafrost, coastal erosion, coastal lagoons, fish, water resources, and potential effects of industrial disturbance on wildlife. From this literature review, we noted evidence for change in the status of some wildlife and their habitats, and the lack of change for others. In the 1002 Area, muskox numbers have decreased and the Porcupine Caribou Herd has exhibited variation in use of the area during the calving season. Polar bears are now more common on shore in summer and fall because of declines in sea ice in the Beaufort Sea. In a study spanning 25 years, there were no significant changes in vegetation quality and quantity, soil conditions, or permafrost thaw in the coastal plain of the 1002 Area. Based on studies from the central Arctic Coastal Plain, there are persistent and emerging uncertainties about the long-term effects of energy development for caribou. In contrast, recent studies that examined direct and indirect effects of industrial activities and infrastructure on birds in the central Arctic Coastal Plain found little effect for the species and disturbances examined, except for the possibility of increased predator activity near human developments.
\end{abstract}

\section{Background}

In 2002, the U.S. Geological Survey (USGS) published a summary of terrestrial wildlife research that was conducted from the 1980s to 2001 in northeastern Alaska, including the 1002 Area of the Arctic National Wildlife Refuge (Douglas and others, 2002). The report focused primarily on wildlife within the 1002 Area, but also included information from adjacent areas of the Arctic Coastal Plain where oil development took place during the preceding 30 years. Since that report was published, the Arctic has continued to warm at more than twice the global rate (Intergovernmental Panel on Climate Change, 2014) and some wildlife species and habitats are responding to climate-induced alterations that include loss of summer sea ice and permafrost thaw, as well as altered nutrient and hydrologic cycling (Chapin and others, 2014; Marcot and others, 2015; Van Hemert and others, 2015).

\footnotetext{
${ }^{1}$ U.S. Geological Survey, Alaska Science Center

${ }^{2}$ U.S. Fish and Wildlife Service, Arctic National Wildlife Refuge
} 
There has also been renewed interest in oil and gas development across the Arctic Coastal Plain of Alaska and offshore in the Outer Continental Shelf region of the Chukchi and Beaufort seas. As a result, substantial research has been conducted in the region in recent years to better understand the mechanisms driving changes in animal abundance and distribution, to provide scientific information for natural resource management agencies, and to guide energy development while reducing potential effects on wildlife and habitat.

Here, we provide an update of Douglas and others (2002) by summarizing recent (2002-17) scientific literature from studies within the 1002 Area of the Arctic National Wildlife Refuge and from terrestrial and coastal ecosystems elsewhere on the Arctic Coastal Plain of Alaska that are relevant to the 1002 Area. This report is organized using the same section titles that appeared in Douglas and others (2002), as well as new sections that describe related wildlife and habitat research within or adjacent to the 1002 Area. The new sections include climate, migratory birds, permafrost, coastal erosion, coastal lagoons, fish, and water resources. In the caribou and migratory bird sections, we summarize recent studies regarding the potential effects of industrial disturbance on wildlife. This report also updates and complements information presented in a USGS report on the natural resources and science needs in the Arctic Outer Continental Shelf region (Holland-Bartels and Pierce, 2011).

\section{Study Area}

The 1002 Area of the Arctic National Wildlife Refuge is a 1,500,000 acre $\left(6,100 \mathrm{~km}^{2}\right)$ area in northeastern Alaska (fig. 1). The approximate boundary of the 1002 Area is bounded on the north by the Beaufort Sea, on the west by the Canning River, and the east by the Aichilik River. The southern boundary follows the approximate 1,000-foot (305-m) elevation contour (Clough and others, 1987). The area is predominantly coastal tundra and upland habitat, often referred to as the 'coastal plain', and includes offshore barrier islands and lagoons (fig. 1). The 1002 Area comprises about 75 percent of the total coastal plain of the Arctic National Wildlife Refuge (Clough and others, 1987). Additional study area details can be found in Douglas and others (2002) and U.S. Fish and Wildlife Service (2015a).

Climate conditions of the 1002 Area and surrounding region have changed over recent decades. Jorgenson and others (2015a) reported that the mean annual temperature at the Kuparuk weather station, $190 \mathrm{~km}$ west of the 1002 Area, increased by $2.5^{\circ} \mathrm{C}$ between 1984 and 2009. Gustine and others (2017) determined that from 1970 to 2013, average air temperatures during the growing season along the Dalton Highway, from the Brooks Range to Prudhoe Bay, showed long-term upward trends, with the greatest increase recorded in the coastal plain near Prudhoe Bay. The rapid increase in May air temperature has driven a trend in markedly earlier snow melt dates, which advanced by about 10 days between 1941 and 2004, leading to a longer growing season (Hinzman and others, 2005). Gustine and others (2017) also determined that day of spring ground thaw $\left(\geq 0{ }^{\circ} \mathrm{C}\right)$ occurred 8 days earlier (range $=2-13$ days) and the length of the vegetation growing season was 11 days longer (range $=0-20$ days) in 2013 than in the 1970s. Warmer air temperatures have been accompanied by warmer nearsurface water temperatures along the coast, which increased by $1.0-1.5^{\circ} \mathrm{C}$ from 2007 to 2011 relative to the 1982-2011 long-term mean (Stroeve and others, 2014). Warmer air and ocean temperatures have altered sea ice extent and phenology, causing the annual number of days the southern Beaufort Sea was covered by ice to decrease at a rate of -17.5 days per decade from 1979 to 2014 (Stern and Laidre, 2016). Since the late 1990s, the mean duration of the open-water season (that is, period of time when sea ice is largely absent from the biologically productive continental shelf) has increased by 36 days (Atwood and others, 2016). 


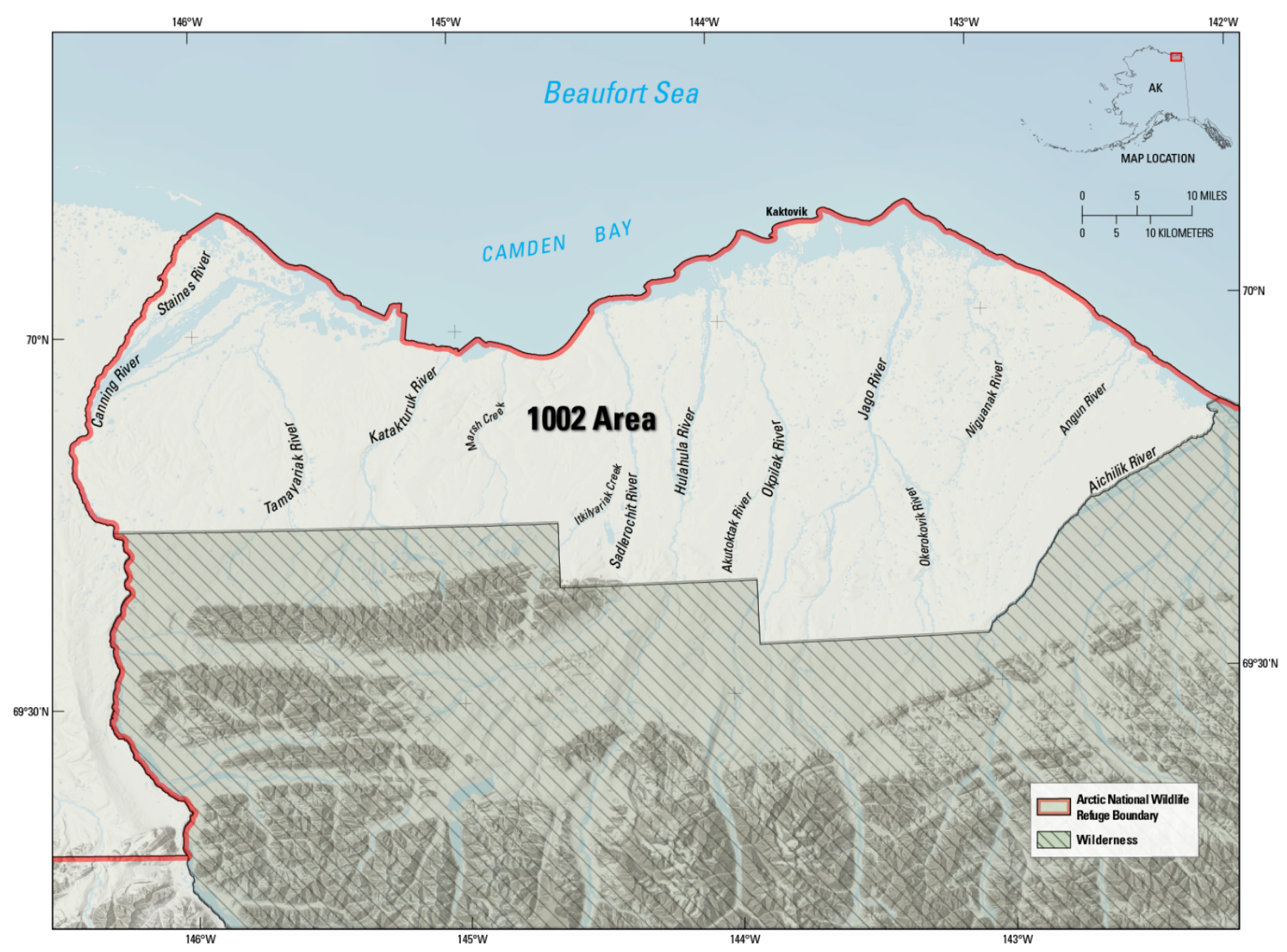

Figure 1. Map of 1002 Area showing approximate boundaries and main rivers, Arctic National Wildlife Refuge, Alaska. Detailed land ownership is not shown. Data source: Bureau of Land Management and Bureau of Ocean Energy Management.

Urban and Clow (2017) provide climate monitoring data collected from August 1998 to July 2015 from an array of 16 monitoring stations across the North Slope of Alaska that span latitude $68.5^{\circ} \mathrm{N}$. to $70.5^{\circ} \mathrm{N}$. and longitude $142.5^{\circ} \mathrm{W}$. to $161^{\circ} \mathrm{W}$. Three of the monitoring stations (Niguanak, Marsh Creek, and Camden Bay) are in the 1002 Area. Data collection at these stations is ongoing and includes the following climate- and permafrost-related variables: air temperature, wind speed and direction, ground temperature, soil moisture, snow depth, rainfall totals, up- and downwelling shortwave radiation, and atmospheric pressure.

\section{Land Cover}

The land-cover map in Jorgenson and others (2002) has not been updated for the 1002 Area, but there have been new releases of land cover information for the entire state of Alaska and North Slope region (Jorgenson and Heiner, 2003; Jorgenson and Grunblatt, 2013; Boggs and others, 2016; Raynolds and others, 2017). Nevertheless, the Jorgenson and others (2002) product remains the highest spatial resolution digital land cover map for the 1002 Area. 


\section{Porcupine Caribou Herd}

The Porcupine Caribou Herd migrates between Alaska and the Yukon and Northwest

Territories of Canada (fig. 2; Caikowski, 2015). Detailed information on herd range characteristics can be found in U.S. Fish and Wildlife Service (2015a). Griffith and others (2002) reported the herd size as 123,000 in 2001. Estimates of population size for the Porcupine Herd were not available between 2002 and 2009, but photocensuses in 2010, 2013, and 2017 demonstrated an increasing trend in population estimates with 169,000, 197,000, and 218,457 caribou counted, respectively (McFarland and others, 2017; Alaska Department of Fish and Game, 2018).

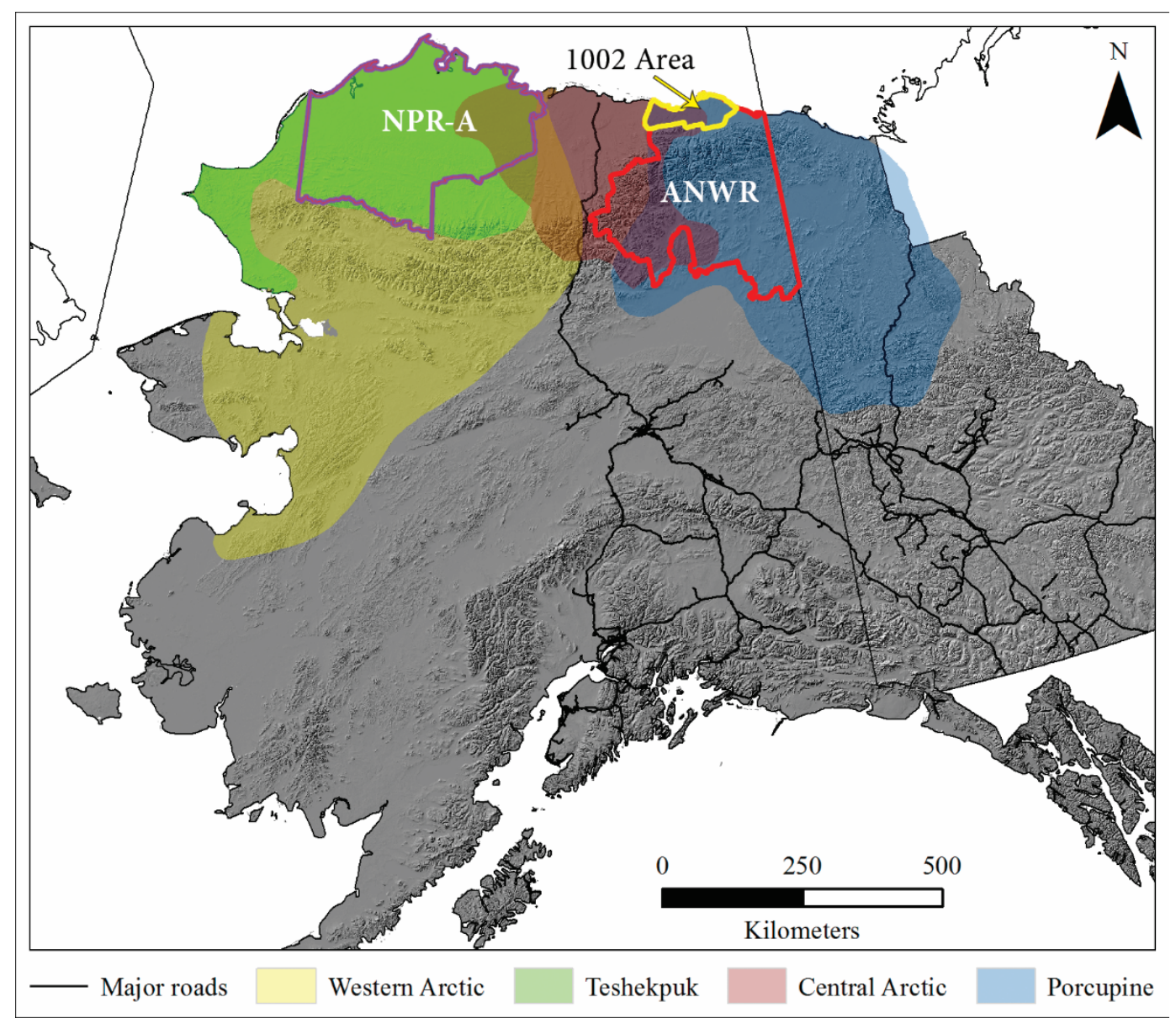

Figure 2. Map of approximate annual distributions of northern caribou herds in Alaska and Canada and approximate boundaries of the National Petroleum Reserve (NPR-A) and 1002 Area, Arctic National Wildlife Refuge (ANWR), Alaska. 
According to Griffith and others (2002) and Harper and McCarthy (2015), much of the Porcupine Herd calved in the Arctic National Wildlife Refuge (often in the 1002 Area) during most years from 1983 to 2001, although some caribou calved in Canada in 1991 and calving areas shifted entirely into Canada in 2000 and 2001 (U.S. Fish and Wildlife Service, 2015a). Maps generated by the U.S. Fish and Wildlife Service (2015a) and McFarland and others (2017) show and discuss calving areas from 2002 to 2017. During these years, Porcupine caribou calving areas vary in location on the coastal plain of northeastern Alaska and northwestern Canada, with animals concentrated in Alaska in some years (2002-03, 2005, 2010, and 2016) and in Canada in others (2004, 2006-07, 2009, and 2011-13). Distribution maps show that caribou appeared to calve in both Alaska and Canada in 2008, 2014-15, and 2017 (U.S. Fish and Wildlife Service, 2015a; McFarland and others, 2017). During several of these years (for example, 2000 and 2001) the shift in calving distribution may have been a response to delayed snow melt on the coastal plain of Alaska (Arthur and Del Vecchio, 2017). The U.S. Fish and Wildlife Service (2015a) concludes that the annual variability in calving area indicates that the Porcupine Caribou Herd needs a large region from which the best conditions for calving can be selected in a given year. The Porcupine Caribou Herd uses the 1002 Area during the post-calving period, but little of this information is publicly available.

Miller and others (2013) determined the abundance of caribou bone and antler specimens of various ages to suggest patterns of caribou use of the coastal plain of the Arctic National Wildlife Refuge over many decades. These data corroborate observed changes in caribou distribution during the period of aerial monitoring (1983-2017).

\section{Central Arctic Caribou Herd}

Prior to 2001, the Central Arctic Caribou Herd spent little time in the 1002 Area and was included in Douglas and others (2002) only as an assessment of the possible effects of oil development on the Porcupine Caribou Herd. Since then, Nicholson and others (2016) published a paper on the annual movements of the herd from 2003 to 2007, and determined that portions of the 1002 Area were used by the Central Arctic Caribou Herd in some years (fig. 2).

The population size of the Central Arctic Caribou Herd increased from 1997 to 2008 at an average rate of approximately 10-13 percent per year before dropping from a high of 70,000 animals in 2010 to approximately 22,000 animals in 2016 (Taras and McFarland, 2016). The Alaska Department of Fish and Game reports that the two major contributing factors to the decline between 2013 and 2016 were high adult female mortality (approximately 50 percent of radio-collared caribou died) and animals switching herds (nearly 20 percent of radio-collared animals were found in either the Porcupine or Teshekpuk herds during the 3-year period; Taras and McFarland, 2016). The authors considered whether the population decline was influenced by range quality, the impact of oil infrastructure, calf production, adult sex ratio, predation, or disease. The authors discuss details for each of these factors and note that research continues into the possible role of these factors in population dynamics of the Central Arctic Caribou Herd. Also relevant to the Central Arctic Herd was a recent study by Gustine and others (2017) that determined that the quality (percent nitrogen) of summer forage for caribou on the coastal plain had not significantly changed between 1977 and 20112013 during peak parturition or lactation. 
Currently (2017), oil and gas development occurs in the calving and summer ranges of the Central Arctic Caribou Herd and the adjacent Teshekpuk Caribou Herd, and has been proposed within the calving and summer range of the Porcupine Caribou Herd. Thus, there are persistent and emerging questions about the effects of indirect habitat loss, displacement of caribou from key calving grounds, and the ability of caribou to move between foraging areas and insect-relief habitat, and ultimately, the influence of these factors on caribou population dynamics (Nellemann and others, 2003). Given these questions, management agencies and energy companies need information about the behavioral effects of development on caribou, whether behavioral responses diminish over time as individuals habituate, and if those responses subsequently influence caribou demographic rates.

The above-ground footprint of oil development within Prudhoe Bay rapidly expanded in the late 1970s and 1980s, with modest increases during more recent years. Studies on the behavioral responses of Central Arctic Herd during the 1980s and early 1990s have indicated that densities of calving caribou declined near roads and as road density increased; calving areas shifted away from infrastructure; and movements between foraging and insect-relief areas were inhibited by roads and pipelines (Smith and Cameron, 1985; Cameron and others, 1992, 1995; Nellemann and Cameron, 1998). In subsequent studies, Pollard and others (1996) determined that caribou densities during the post-calving season (July and August) were approximately ten-fold greater in the vicinity of Prudhoe Bay when relative insect activity was moderate or high, and that some caribou used elevated roads and well pads for insect relief. Haskell and others (2006) speculated that among-year changes in the caribou distribution within $1 \mathrm{~km}$ of roads may have been due to partial habituation to infrastructure. All these studies were largely based on data from aerial or road surveys, where the limited frequency (for aerial surveys) and spatial distribution (for road surveys) of data collection potentially introduced bias (Joly and others, 2006). As a result, studies over broader spatial scales and longer time frames are needed to reliably identify important habitats near potential energy infrastructure (Wilson and others, 2012) and understand the cumulative effects of oil and gas development on caribou, including the possibility of habituation to infrastructure and other human disturbances (Johnson and Russell, 2014).

Arthur and Del Vecchio (2009) tested for differences in calf growth and survival between the less-developed eastern and more industrialized western calving ranges of the Central Arctic Herd (see fig. 1 of Arthur and Del Vecchio, 2009). From 2001 to 2007, the authors observed that birth mass and skeletal growth of calves was higher in less-developed areas, but that calf survival did not differ between the two areas. Although the power to detect changes in demographic rates was limited by sample size, the authors suggested their findings may be evidence that caribou using the lessdeveloped eastern area were in better condition. However, the authors stated that because of other changes (density dependence, shifting distributions, and habitat conditions) that took place in the summer range during the period of oil development, differences between western and eastern areas do not necessarily imply effects of industrial activity, and that there is sufficient variability in habitat quality across the range of the Central Arctic Herd to affect calf size, which may in turn influence calf recruitment into the population.

Nicholson and others (2016) developed movement models of the Central Arctic Caribou Herd to estimate and quantify summer and winter ranges of adult females, to assess annual variation in these ranges, and to identify areas used during spring and fall migration. The authors determined considerable variation in range use during 4 years of monitoring and suggested that the high variability indicates that caribou may have altered their use of winter range based on inter-annual differences in winter weather, snow cover, forage characteristics, or other factors. The authors also found that caribou movements during 4 years of migration were too variable to enable use of a single model that could adequately describe movements of all individuals. Caribou migration routes used during this study varied among years, but some areas of concentrated use ("bottlenecks") were used consistently by large numbers of caribou in all years. Nicholson and others (2016) suggested that these migration bottlenecks should be managed to provide for continued access by caribou. 


\section{Forage Quantity and Quality}

Two recent studies examined changes in forage quantity and quality for ungulates and overall vegetation characteristics in the 1002 Area. First, Arthur and Del Vecchio (2013) examined fecal, soil, and vegetation samples collected during July 2009 to determine the role of forage quality in the decrease of muskoxen in northeastern Alaska. No differences were detected in mean concentrations of most mineral nutrients in soil and plant samples from sites used by muskoxen from 2007 to 2009 compared to sites that were used prior to 2006, but not in subsequent years. However, mineral concentrations of copper $(\mathrm{Cu})$ in wideleaf polargrass (Arctagrostis latifolia) were well below minimum levels required for livestock and concentrations of zinc $(\mathrm{Zn})$ in willow (Salix alaxensis) exceeded maximum levels recommended for livestock (Arthur and Del Vecchio, 2013).

Second, Jorgenson and others (2015a) summarized 25 years of vegetation plot data in the 1002 Area. This study monitored plant cover at 27 plots in 7 different years during 1984-2009 between the Katakturuk and Aichilik Rivers and quantified cover of all plant species and assessed change over time. Overall, the authors found that vegetation in the plots changed little in contrast to results from other studies in northern Alaska (see references in Jorgenson and others, 2015a). For the few plots with differences over time, the authors attributed the change to subsidence from thawing ground ice or floodplain dynamics. Jorgenson and others (2015a) remarked that the lack of an increasing trend in shrub cover in study plots was unexpected as this type of vegetation transition is occurring in many other parts of northern Alaska.

\section{Predators}

In Douglas and others (2002), the geographic distribution of golden eagle (Aquila chrysaetos) nest sites, wolves (Canis lupus), and brown bears (Ursus arctos) within and adjacent to the 1002 Area were surveyed and mapped. Eagle and wolf distributions were based on aerial surveys and brown bear distributions were based on annual locations of radio-collared bears during the first week of June from 1983 to 1994. There has been no update of this information for the 1002 Area since 2002.

\section{Muskoxen}

The population of muskoxen in northeastern Alaska (Colville River east to the Canadian border) declined from a peak of 700 animals in 1995 to approximately 216 in 2006 (Arthur and Del Vecchio, 2013; Afema and others, 2017). Within just the coastal plain of the Arctic National Wildlife Refuge, muskoxen virtually disappeared by 2006 between the Canning River and the Canadian border (Arthur and Del Vecchio, 2017). The population decline was less severe (35 percent) between the Colville River and the Canning River. According to Afema and others (2017) there are no known observed climatic, anthropogenic, or other environmental influences that provide a plausible explanation for the observed population decline of muskoxen in northeastern Alaska. Arthur and Del Vecchio (2017) state that the availability of moose and caribou calves as prey for brown bears was greatly reduced because of a moose population decline in the mid-1990s and a shift in the calving distribution of the Porcupine Caribou Herd to areas farther east in northern Canada during 2000 and 2001. Thus, Arthur and Del Vecchio (2017) suggest that reduced availability of other prey species may have caused some bears to focus predation on muskoxen, thus potentially contributing to the muskox population decline. Although predation by brown bears was the most common cause of death for muskox calves, the population decline was likely caused by a combination of factors acting in combination with predation, including disease, poor nutrition, low calf productivity and recruitment as well as poor survival of adults (Arthur and Del Vecchio, 2017). 
Afema and others (2017) found evidence for multiple diseases that potentially contributed to the mortality of muskoxen. Afema and others (2017) concluded that the northeastern muskox population was adversely affected by complex nutritional and infectious disease dynamics resulting in comorbidity that also likely increased susceptibility to predation. Analysis of fecal, soil, and vegetation samples collected between 2007 and 2011 by Arthur and Del Vecchio (2013) indicate that grasses and sedges were the most common forage types for both coastal and more inland muskox groups. There was some evidence of differences in diet between coastal and inland groups, but sample sizes were insufficient for meaningful statistical comparisons.

\section{Polar Bears}

Polar bears of the Southern Beaufort Sea subpopulation historically spent the entire year on the sea ice, with the exception of a relatively small proportion of adult females that would come ashore during autumn and enter maternity dens. However, over the last two decades, the southern Beaufort Sea has experienced a marked decline in summer sea ice extent, along with a pronounced lengthening of the melt season (period of time between sea ice break-up and freeze-up; Stroeve and others, 2014; Stern and Laidre, 2016). The dramatic changes in the extent and phenology of sea ice habitat during summer and prior to denning have coincided with evidence suggesting that use of terrestrial habitat has increased, including in the Arctic National Wildlife Refuge 1002 Area.

Schliebe and others (2008) determined that an average of 4 percent of the Southern Beaufort Sea subpopulation of polar bears was on land in a given autumn during 2000-2005, and that the percentage increased when sea ice was farther from the coast. More recently, Atwood and others (2016) determined that the percentage of radio-collared adult females coming ashore in summer and fall increased from 5.8 to 20 percent between 2000 and 2014. Over the same period, the mean duration of the open-water season (the period when $<15$ percent of the continental shelf is covered by $\geq 15$ percent concentration sea ice) increased by 36 days and the mean length of stay on land by polar bears increased by 31 days (Atwood and others, 2016). While on shore, the distribution of polar bears is largely influenced by the opportunity to feed on the remains of subsistence-harvested bowhead whales aggregated at 3 sites along the coast, including adjacent to the community of Kaktovik (Rogers and others, 2015; McKinney and others, 2017; Wilson and others, 2017) (fig. 3).

In addition to using land as refugia during the open-water season, Southern Beaufort Sea polar bears have increasingly used land for maternal denning. Olson and others (2017) examined the choice of denning substrate (land compared to sea ice) by adult females between 1985 and 2013 and determined that the frequency of land-based denning increased over time, constituting 34.4 percent of all dens from 1985 to 1995, 54.6 percent from 1996 to 2006, and 55.2 percent from 2007 to 2013. Additionally, the frequency of land denning was directly related to the distance that sea ice retreated from the coast. From 1985-1995 and 2007-2013, the average distance from the coast to 50 percent sea ice concentration in September (when sea ice extent reaches its annual minimum) increased $351 \pm 55$ $\mathrm{km}$, while the distance to 15 percent sea ice concentration increased by $275 \pm 54 \mathrm{~km}$. Rode and others (2018) determined that reproductive success was greater for females occupying land-based dens compared to ice-based dens, which may be an additional factor contributing to the increase in landbased denning. Land-based dens are mostly distributed along the central and eastern coast of Alaska's Beaufort Sea, which includes the 1002 Area (Durner and others, 2010; fig. 4). Durner and others (2006) estimate there is approximately 3,020 linear kilometers of suitable denning habitat within the 1002 Area (fig. 5). 
Collectively, these results suggest that the use of land by polar bears as summer refugia and for denning in winter will likely continue to increase with additional loss of sea ice. Although the effects that increased land use may have on nutrition, energetics, and reproduction are not fully understood, it is worth noting that the Southern Beaufort Sea subpopulation of polar bears has experienced a recent decline in abundance (Bromaghin and others, 2015). Increased frequency of bears on land, coupled with expanding human activities, is expected to lead to greater human-polar bear interaction and conflict (Atwood and others, 2016). The increased numbers of bears on land in the vicinity of Kaktovik has also led to a dramatic increase in popularity of commercially guided polar bear viewing. This industry was virtually non-existent in Kaktovik before 2006, but through 2016 more than 2,300 viewer-trips were recorded during the 61-day commercial viewing season (some viewers may have participated in multiple trips; Reed and Duplisea, 2017). This use greatly exceeds the total use by all other recreational activities in the Arctic National Wildlife Refuge.

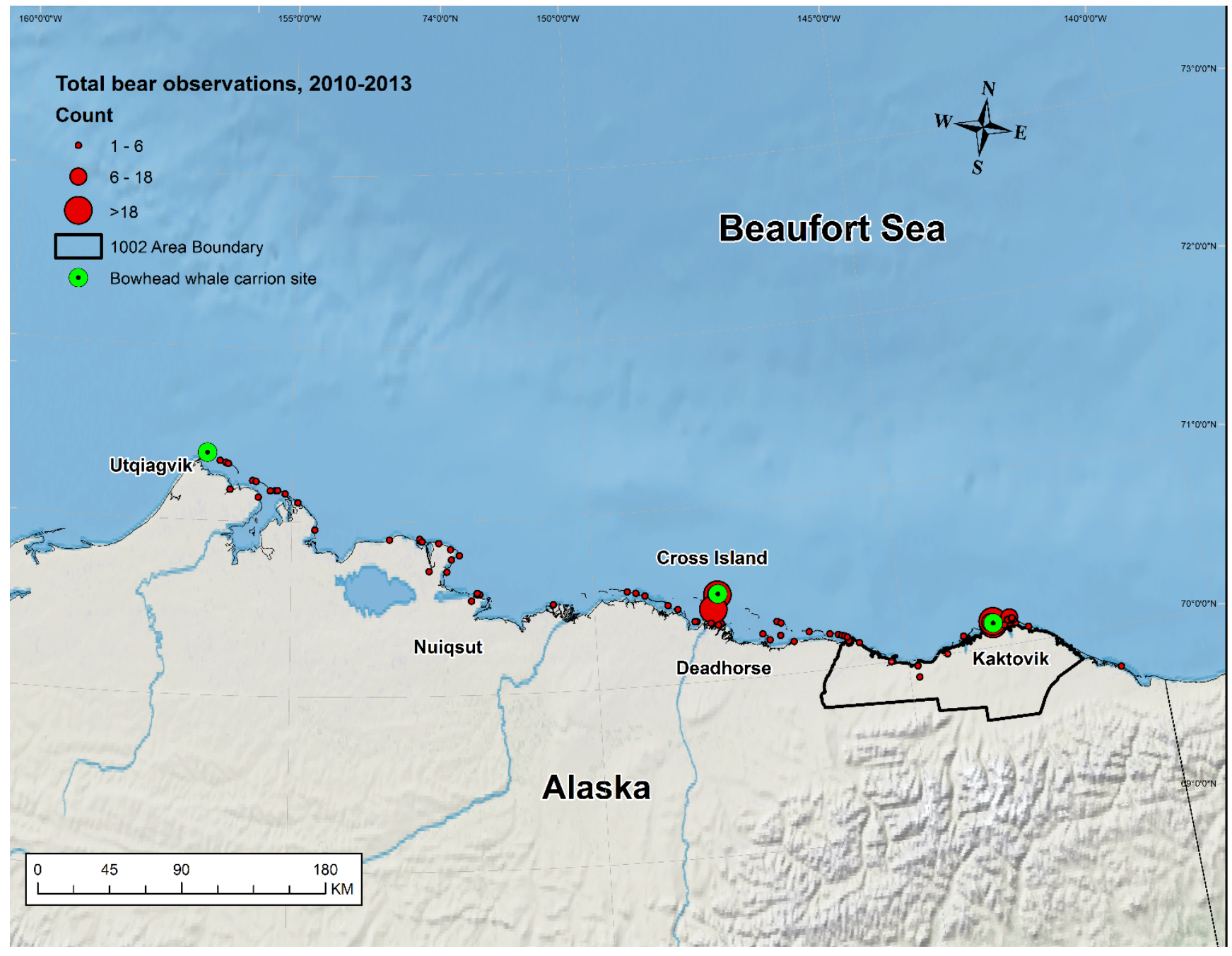

Figure 3. Map showing distribution of polar bears observed from 2010 to 2013 during autumn aerial surveys along the north coast, Alaska. The black line shows the approximate boundary of the 1002 Area, Arctic National Wildlife Refuge. (Adapted from Atwood and others, 2016). 


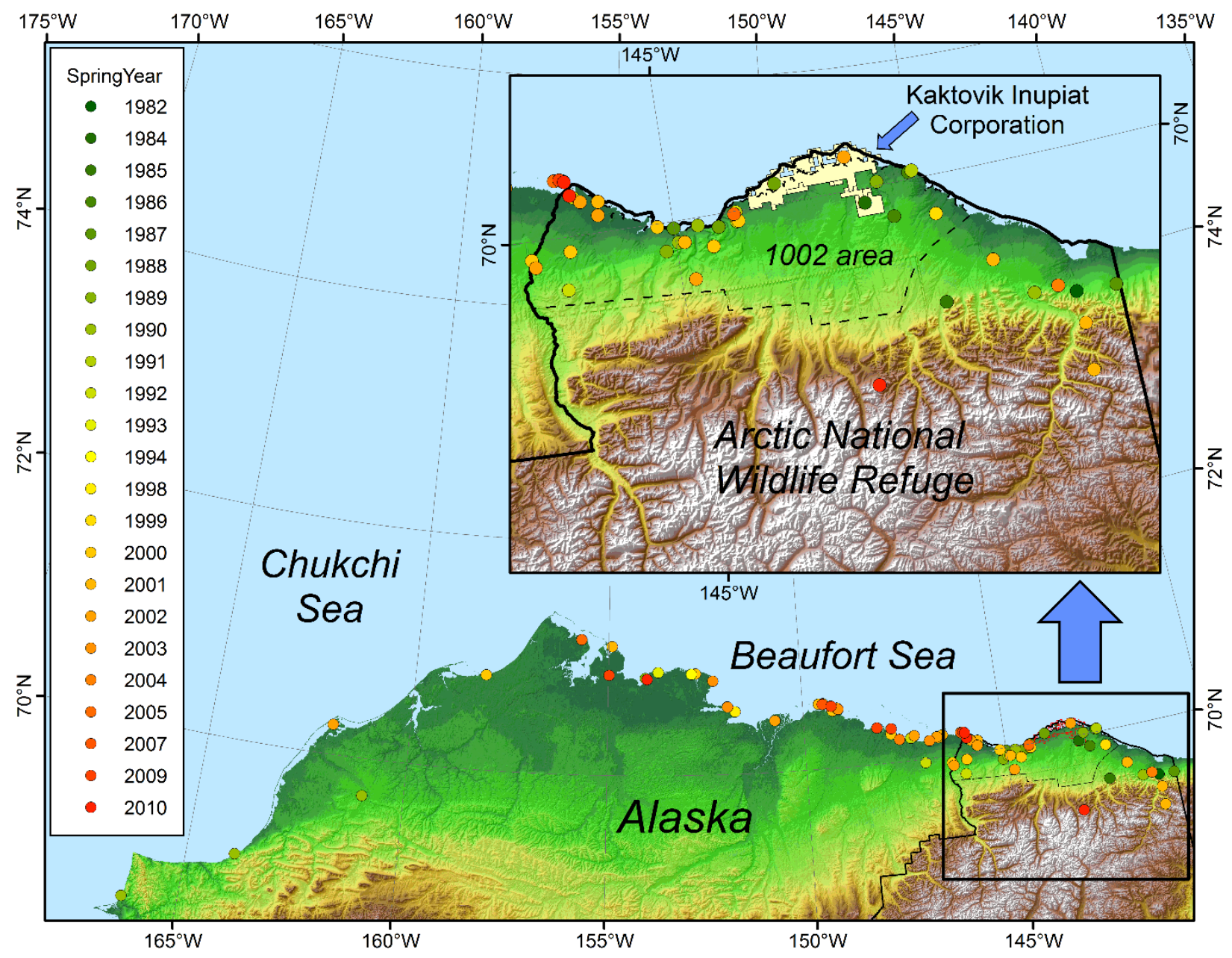

Figure 4. Map showing polar bear maternal dens on land or fast ice discovered with very high frequency (VHF) or satellite telemetry along north coast, Alaska, 1982-2010. Polar bears den during winter and "Spring Year" denotes the year the den was exited. The dashed line shows the approximate boundary of the 1002 Area, Arctic National Wildlife Refuge, Alaska. 


\section{Beaufort Sea}

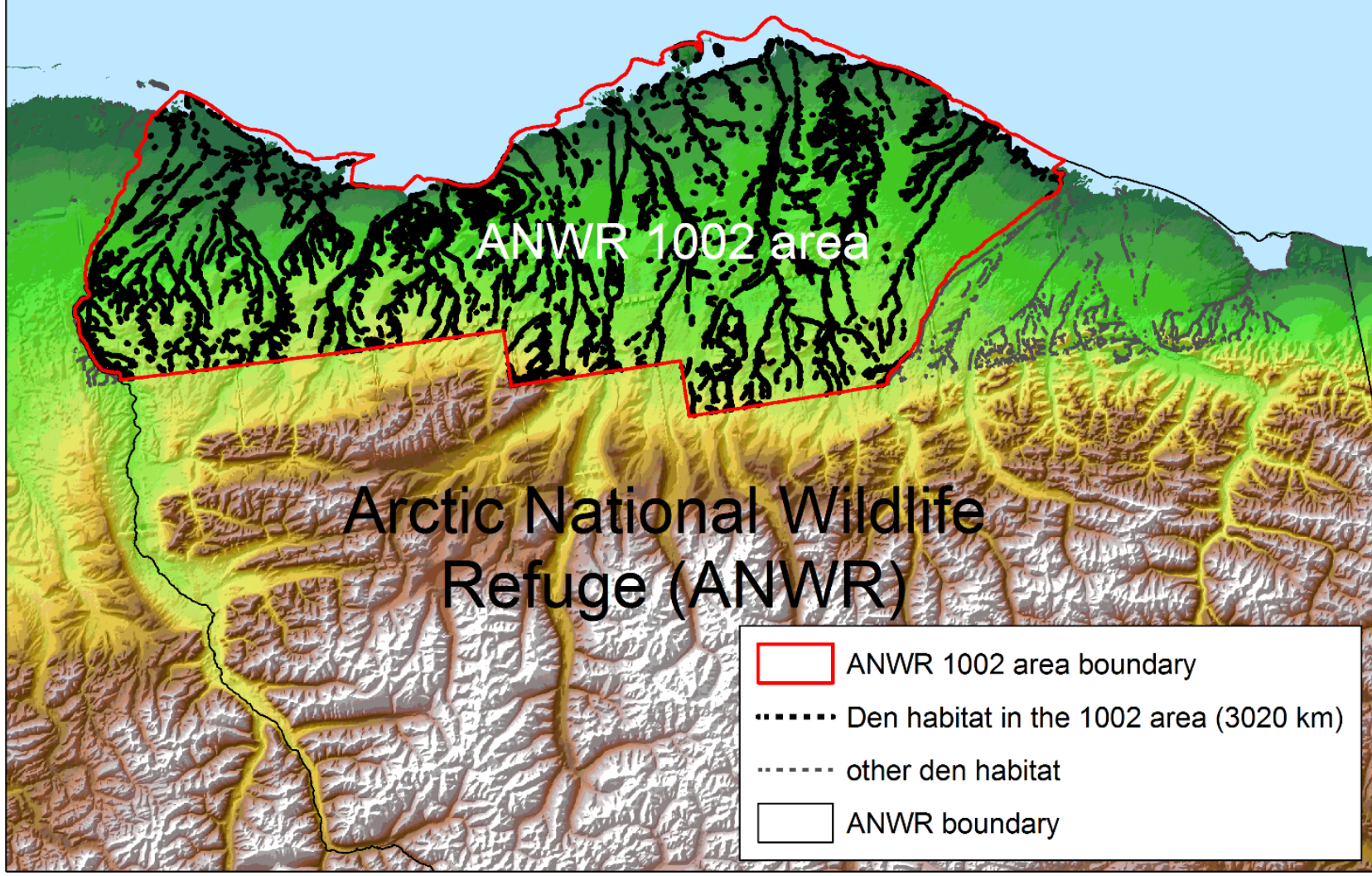

Figure 5. Map showing estimate of suitable polar bear maternal denning habitat within the approximate boundary of the 1002 Area, Arctic National Wildlife Refuge, Alaska. (Based on Durner and others, 2006). 


\section{Snow Geese}

Snow geese are one of the most abundant bird species in the 1002 Area, but use is mostly for autumn staging after the breeding season. The Arctic National Wildlife Refuge is part of a larger staging area that extends east from the U.S. and Canadian border for approximately $500 \mathrm{~km}$ along the Arctic Coastal Plain to the Bathurst Peninsula of Canada. Snow geese that use the coastal staging area mainly originate from nesting areas on Banks Island in Canada. That population has increased to about 500,000 breeding individuals from the 200,000 birds present in the early 1990s (Pacific Flyway Council, 2013). Elsewhere on the Arctic Coastal Plain of Alaska, the number of breeding snow geese is rapidly increasing (Burgess and others, 2017; Hupp and others, 2017). Burgess and others (2017) suggest that some of the increase in Alaska may be due to immigration of snow geese from expanding breeding populations in the Canadian Arctic.

Since 1986, the U.S. Fish and Wildlife Service Migratory Bird Management Office has conducted annual aerial surveys of the Arctic Coastal Plain to generate indices of nesting waterbird population size and trends over time (Stehn and others, 2013). The 1002 Area is within the low bird density strata with transects that are widely spaced resulting in low power to detect clumped distributions of birds, such as snow geese that nest in colonies. There is uncertainty regarding current population status of snow geese staging within the 1002 Area. Maximum counts of autumn staging snow geese made in most years between 1973 and 2004 through a variety of survey methods are summarized by the U.S. Fish and Wildlife Service (2015a). In 2004, the last survey for which data are available, a total of 189,636 birds was observed on the coastal plain. Given the overall increase in numbers of snow geese in Arctic Alaska and Canada, further increases in the use of autumn staging areas in the 1002 Area should be expected.

\section{Additional Wildlife and Habitat Research}

\section{Migratory Birds}

The U.S. Fish and Wildlife Service (2015b) lists a total of 201 migratory bird species for the entirety of the Arctic National Wildlife Refuge. The 201 species total is a cumulative number, generated over many years of observations and includes species that were only seen once and those seen frequently each year across the refuge. At least 57 species regularly occur as breeding, nonbreeding, or both in the 1002 Area (table 1). These are species recorded on the coastal plain or nearshore areas of the Beaufort Sea as "fairly common", "common", or "abundant". 
Table 1. List of 57 fairly common, common, and abundant breeding and nonbreeding bird species for the coast, inland, and barrier island and lagoon regions of the 1002 Area of the Arctic National Wildlife Refuge, Alaska.

[Species: Species names and order follows Chesser and others (2017). Reference: Source references used are: 1, Garner and Reynolds (1986); 2, Garner and Reynolds (1987); 3, Brown and others (2007); 4, Dau and Bollinger (2009); 5, U.S. Fish and Wildlife Service (2015b); 6, Kendall (2005). Generalized categories of abundance were used by most references since few quantitative surveys have been conducted in the 1002 Area. For Dau and Bollinger (2009), we did not include species with less than or equal to 15 average sightings per year (see table 2). In cases where habitat area is given as "coastal plain" by a reference, both coast and inland areas are included. Abbreviations: B, breeding, NB, non-breeding]

\begin{tabular}{|c|c|c|c|c|}
\hline \multirow[b]{2}{*}{ Species } & \multicolumn{3}{|c|}{ Region within 1002 Area } & \multirow[b]{2}{*}{ Reference } \\
\hline & Coast & Inland & $\begin{array}{c}\text { Barrier } \\
\text { Islands and } \\
\text { Lagoons }\end{array}$ & \\
\hline Greater white-fronted goose (Anser albifrons) & NB & NB & & $1,2,5$ \\
\hline Snow goose (Anser caerulescens) & NB & NB & & $1,2,5$ \\
\hline Brant (Branta bernicla) & $\mathrm{B}, \mathrm{NB}$ & & NB & $1,2,4$ \\
\hline Cackling goose (Branta hutchinsii) & $\mathrm{B}, \mathrm{NB}$ & $\mathrm{B}, \mathrm{NB}$ & & $1,2,5$ \\
\hline Tundra swan (Cygnus columbianus) & $\mathrm{B}, \mathrm{NB}$ & $\mathrm{B}, \mathrm{NB}$ & & $1,2,5,6$ \\
\hline American wigeon (Mareca americana) & NB & & & 1 \\
\hline Northern pintail (Anas acuta) & $\mathrm{B}, \mathrm{NB}$ & $\mathrm{B}, \mathrm{NB}$ & NB & $1,2,4,5$ \\
\hline Greater scaup (Aythya marila) & NB & & NB & 1,4 \\
\hline King eider (Somateria spectabilis) & $\mathrm{B}, \mathrm{NB}$ & & NB & $2,4,5$ \\
\hline Common eider (Somateria mollissima) & NB & & $\mathrm{B}, \mathrm{NB}$ & $1,2,4,5,6$ \\
\hline Surf scoter (Melanitta perspicillata) & & & NB & 1,4 \\
\hline White-winged scoter (Melanitta fusca) & NB & & NB & $4,5,6$ \\
\hline Long-tailed duck (Clangula hyemalis) & $\mathrm{B}, \mathrm{NB}$ & $\mathrm{B}$ & NB & $1,2,4,5,6$ \\
\hline Red-breasted merganser (Mergus serrator) & NB & $\mathrm{B}$ & NB & $1,2,4,5,6$ \\
\hline Willow ptarmigan (Lagopus lagopus) & $\mathrm{B}, \mathrm{NB}$ & $\mathrm{B}, \mathrm{NB}$ & & $1,2,5$ \\
\hline Rock ptarmigan (Lagopus muta) & $\mathrm{B}, \mathrm{NB}$ & $\mathrm{B}, \mathrm{NB}$ & & $1,2,5$ \\
\hline Sandhill crane (Antigone canadensis) & NB & & & 2 \\
\hline Black-bellied plover (Pluvialis squatarola) & NB & & & $1,2,5$ \\
\hline American golden-plover (Pluvialis dominica) & $\mathrm{B}, \mathrm{NB}$ & $\mathrm{B}, \mathrm{NB}$ & & $1,2,3,5$ \\
\hline Semipalmated plover (Charadrius semipalmatus) & & $\mathrm{B}, \mathrm{NB}$ & & 2,5 \\
\hline Upland sandpiper (Bartramia longicauda) & & $\mathrm{B}$ & & 5 \\
\hline Whimbrel (Numenius phaeopus) & & NB & & 2 \\
\hline Ruddy turnstone (Arenaria interpres) & $\mathrm{B}, \mathrm{NB}$ & $\mathrm{B}, \mathrm{NB}$ & & $1,2,5$ \\
\hline Stilt sandpiper (Calidris himantopus) & $\mathrm{B}, \mathrm{NB}$ & $\mathrm{B}$ & & 1,2 \\
\hline Sanderling (Calidris alba) & NB & & & 2 \\
\hline Dunlin (Calidris alpina) & $\mathrm{B}, \mathrm{NB}$ & $\mathrm{B}$ & & $1,2,3$ \\
\hline Baird's sandpiper (Calidris bairdii) & $\mathrm{B}$ & NB & & 1,2 \\
\hline Buff-breasted sandpiper (Calidris subruficollis) & $\mathrm{B}$ & $\mathrm{B}$ & & 1,2 \\
\hline Pectoral sandpiper (Calidris melanotos) & $\mathrm{B}, \mathrm{NB}$ & $\mathrm{B}, \mathrm{NB}$ & & $1,2,3,5,6$ \\
\hline Semipalmated sandpiper (Calidris pusilla) & $\mathrm{B}, \mathrm{NB}$ & $\mathrm{B}, \mathrm{NB}$ & & $1,2,3,5$ \\
\hline Western sandpiper (Calidris mauri) & NB & & & 1,2 \\
\hline Long-billed dowitcher (Limnodromus scolopaceus) & $\mathrm{B}, \mathrm{NB}$ & $\mathrm{B}, \mathrm{NB}$ & & $1,2,5$ \\
\hline Red-necked phalarope (Phalaropus lobatus) & $\mathrm{B}, \mathrm{NB}$ & $\mathrm{B}$ & & $1,2,3,5$ \\
\hline Red phalarope (Phalaropus fulicarius) & $\mathrm{B}, \mathrm{NB}$ & $\mathrm{B}, \mathrm{NB}$ & & $1,2,3,5$ \\
\hline Pomarine jaeger (Stercorarius pomarinus) & $\mathrm{B}, \mathrm{NB}$ & $\mathrm{B}, \mathrm{NB}$ & & $1,2,5$ \\
\hline
\end{tabular}




\begin{tabular}{|c|c|c|c|c|}
\hline \multirow[b]{2}{*}{ Species } & \multicolumn{3}{|c|}{ Region within 1002 Area } & \multirow[b]{2}{*}{ Reference } \\
\hline & Coast & Inland & $\begin{array}{c}\text { Barrier } \\
\text { Islands and } \\
\text { Lagoons }\end{array}$ & \\
\hline Parasitic jaeger (Stercorarius parasiticus) & NB & NB & & $1,2,5$ \\
\hline Long-tailed jaeger (Stercorarius longicaudus) & $\mathrm{B}, \mathrm{NB}$ & $\mathrm{B}, \mathrm{NB}$ & & $1,2,5$ \\
\hline Glaucous gull (Larus hyperboreus) & $\mathrm{B}, \mathrm{NB}$ & NB & $\mathrm{B}, \mathrm{NB}$ & $1,2,4,5,6$ \\
\hline Arctic tern (Sterna paradisaea) & NB & NB & $\mathrm{B}$ & $1,2,5,6$ \\
\hline Red-throated loon (Gavia stellata) & $\mathrm{B}, \mathrm{NB}$ & & NB & $1,2,4,5,6$ \\
\hline Pacific loon (Gavia pacifica) & $\mathrm{B}, \mathrm{NB}$ & $\mathrm{B}, \mathrm{NB}$ & NB & $1,2,4,5,6$ \\
\hline Yellow-billed loon (Gavia adamsii) & NB & & NB & 2 \\
\hline Rough-legged hawk (Buteo lagopus) & NB & NB & & 2 \\
\hline Golden eagle (Aquila chrysaetos) & NB & NB & & $1,2,5$ \\
\hline Snowy owl (Bubo scandiacus) & $\mathrm{B}, \mathrm{NB}$ & $\mathrm{B}, \mathrm{NB}$ & & $1,2,5$ \\
\hline Short-eared owl (Asio flammeus) & $\mathrm{B}$ & $\mathrm{B}$ & & $1,2,5$ \\
\hline Peregrine falcon (Falco peregrinus) & NB & & & 2 \\
\hline Common raven (Corvus corax) & & NB & & 2 \\
\hline Eastern yellow wagtail (Motacilla tschutschensis) & $\mathrm{B}$ & $\mathrm{B}, \mathrm{NB}$ & & $1,2,5$ \\
\hline Common redpoll ${ }^{1}$ (Acanthis flammea) & $\mathrm{B}$ & $\mathrm{B}$ & & $1,2,5$ \\
\hline Hoary redpoll ${ }^{1}$ (Acanthis hornemanni) & $\mathrm{B}$ & $\mathrm{B}$ & & $1,2,5$ \\
\hline Lapland longspur (Calcarius lapponicus) & $\mathrm{B}$ & $\mathrm{B}$ & & $1,2,5$ \\
\hline Snow bunting (Plectrophenax nivalis) & $\mathrm{B}$ & $\mathrm{B}$ & $\mathrm{B}, \mathrm{NB}$ & 5,6 \\
\hline American tree sparrow (Spizelloides arborea) & & $\mathrm{B}$ & & $1,2,5$ \\
\hline Savannah sparrow (Passerculus sandwichensis) & $\mathrm{B}$ & $\mathrm{B}$ & & $1,2,5$ \\
\hline White-crowned sparrow (Zonotrichia leucophrys) & & $\mathrm{B}$ & & 1 \\
\hline
\end{tabular}

The only bird species listed under the provisions of the Endangered Species Act of 1973 that are known to occur in the 1002 Area are the threatened Alaska-breeding population of the Steller's eider (Polysticta stelleri) and threatened spectacled eider (Somateria fischeri). These species have populations in northern Alaska that range from 576 birds (292-859: 90-percent confidence interval [CI]) for the Steller's eider (Stehn and Platte, 2009) to an average index of 7,158 total birds (6,5367,781: 90-percent CI) for spectacled eiders (Stehn and others, 2013). Steller's eiders are concentrated in the western portion of the Arctic Coastal Plain near Utqiagivik (formerly Barrow); whereas spectacled eiders are more widely distributed across the Arctic Coastal Plain. The Steller's eider is listed as a "rare visitor" and is not known to breed in the 1002 Area. However, the spectacled eider is listed as a "rare breeder" on the coastal plain of the Arctic National Wildlife Refuge (U.S. Fish and Wildlife Service, 2015), but it is not known how many nests occur annually within the 1002 Area.

Since 1986, the U.S. Fish and Wildlife Service has conducted annual aerial surveys of much of the Arctic Coastal Plain of northern Alaska to generate indices of nesting waterbird population size and trends over time (Stehn and others, 2013). However, only about one-third of the 1002 Area is currently surveyed, and what is surveyed falls within the low-density strata. Surveys within the lowdensity strata have far fewer transects that are farther apart and thus have little power to detect and determine trends of breeding and non-breeding migratory birds. 
Bart and others (2013) used aerial and ground survey data to estimate distribution, abundance, and density of 3 groups of aquatic birds (waterfowl, loons, and grebes; shorebirds; and gulls, terns, and jaegers) across much of the Arctic Coastal Plain. They reported a west-to-east gradient of abundance and density of these 3 groups, with higher numbers in the west (National Petroleum Reserve - Alaska [NPR-A]), intermediate numbers in the central coastal plain (Prudhoe Bay), and lower numbers in the east (Arctic National Wildlife Refuge).

Kendall (2005) searched the barrier islands of the 1002 Area on foot in the summers of 20032004 and documented a total of 229 common eider nests. From 1999 to 2009, during late June and early July, Dau and Bollinger (2009) conducted aerial surveys in nearshore waters and along barrier islands of the Arctic Coastal Plain, including areas within the 1002 Area, to count common eiders (Somateria mollissima) and other waterbirds. A summary of average numbers of the most common waterbirds counted during these aerial surveys that occurred within the 1002 Area (survey segments 22-27) is presented in table 2. Additionally, Lysne and others (2004) conducted near-shore sea duck and loon aerial surveys in late July and early August of 2002 and 2003 along the coast of the Arctic National Wildlife Refuge. The authors documented similar species to Dau and Bollinger (2009), but observed thousands more long-tailed ducks (Clangula hyemalis) during the surveys.

Table 2. Average number per year of the 17 most common bird species observed from 1999 to 2009 on coastal lagoon and barrier island aerial surveys within the 1002 Area of the Arctic National Wildlife Refuge, Alaska.

[From U.S. Fish and Wildlife Service (Dau and Bollinger, 2009). Species: Species names and order follows Chesser and others (2017)]

\begin{tabular}{lc}
\hline \multicolumn{1}{c}{ Species } & $\begin{array}{c}\text { Average } \\
\text { number }\end{array}$ \\
\hline Brant (Branta bernicla) & 45 \\
Cackling goose (Branta hutchinsii) & 12 \\
Tundra swan (Cygnus columbianus) & 7 \\
Northern pintail (Anas acuta) & 44 \\
Greater scaup (Aythya marila) & 179 \\
King eider (Somateria spectabilis) & 184 \\
Common eider (Somateria mollissima) & 593 \\
Surf scoter (Melanitta perspicillata) & 2,173 \\
White-winged scoter (Melanitta fusca) & 271 \\
Long-tailed duck (Clangula hyemalis) & 819 \\
Red-breasted merganser (Mergus serrator) & 306 \\
Glaucous gull (Larus hyperboreus) & 553 \\
Arctic tern (Sterna paradisaea) & 5 \\
Red-throated loon (Gavia stellata) & 15 \\
Pacific loon (Gavia pacifica) & 38 \\
Yellow-billed loon (Gavia adamsii) & 4 \\
\hline
\end{tabular}




\section{Shorebirds}

The Arctic Coastal Plain of Alaska is an important region for millions of migrating and nesting shorebirds. Brown and others (2007) conducted surveys of breeding shorebirds during June of 2002 and 2004. They encountered 14 shorebird species and estimated that 230,000 (95-percent CI: 104,000$363,000)$ shorebirds occupied the 1002 Area during the breeding season. Species richness and density were typically highest in wetland or riparian habitats and deltas (such as near the Canning River Delta). Johnson and others (2007) determined that shorebird species were more abundant in the coastal ecoregion (that is, closer to the coast rather than farther inland) and that across the entire Arctic Coastal Plain, species richness was highest in the western part of the Beaufort coastal plain. However, several species were more abundant in the east, reflecting longitudinal diversity. Johnson and others (2007) concluded that the distribution maps of their study would be helpful for documenting largescale shifts in species ranges, but that more detailed habitat-based maps would be needed to document subtle changes in distribution.

Saalfeld and others (2013a) developed habitat suitability models for eight species of shorebirds across the Arctic Coastal Plain. Like Johnson and others (2007), they determined that the most suitable habitat was in the NPR-A, followed by the Arctic National Wildlife Refuge. The authors also noted that because habitat suitability maps depict areas with minimum habitat requirements for a given species, ground surveys should be conducted prior to establishing final recommendations for any future development to verify the use of an area by nesting shorebirds.

Taylor and others (2010) used aerial surveys of the entire northern coast of Alaska during summers of 2005-07 to locate concentrations of staging shorebirds and determine species richness and composition, seasonal phenology, and habitat selection. The authors noted large concentrations of staging shorebirds on the Sagavanirktok and Kongakut river deltas. A comparison to data collected in the mid-1970s indicated that foraging habitat types used by staging shorebirds were largely unchanged through time. Taylor and others (2011) subsequently used radio transmitters on shorebirds to determine species movements and residence times on the Arctic Coastal Plain following the breeding season. Results demonstrated how different species use the northern Alaska coast and suggest that individuals use multiple post-breeding sites as they migrate eastward before ultimately moving south down the Central Flyway. Brown and others (2012) used a transect survey of Arctic National Wildlife Refuge river deltas, and determined that most of the deltas were used by large numbers of shorebirds during fall migration with the Jago River Delta being one of the highest use areas.

Churchwell and others $(2016,2017)$ examined the diversity and annual variation of benthic invertebrate communities within the Canning, Okpilak, Hulahula, and Jago river deltas in the coastal part of the 1002 Area. Churchwell and others (2016) found both freshwater and marine organisms were present and that species diversity was relatively low in comparison to river deltas at more southerly latitudes. The benthic resources provide food for large numbers of migratory shorebirds during the summer open-water period. Semipalmated sandpipers (Calidris pusilla) used the Jago River Delta in large numbers early in the migration (around August 1) and the Okpilak/Hulahula River Delta later in migration (around August 13; Churchwell and others, 2017). Based on analyses of stable isotopes in their diet, shorebirds fed on benthic invertebrates that were patchily abundant, but preferred prey were not always the most abundant invertebrate species present on a given delta (Churchwell and others, 2017). Accordingly, different invertebrate species were the apparent preferred prey at each delta. 


\section{Disturbance to Birds from Industry and Investigators}

A number of recent studies have examined direct and indirect effects of industrial activities to birds on the Arctic Coastal Plain. Saalfeld and others (2013b) examined productivity of nesting shorebird species in relation to the development of a landfill near Utqiagivik and found that nest densities, nest survival, and return rates were generally greater inside than outside a fenced area surrounding the landfill. Bart and others (2013) examined aerial survey data within the Prudhoe Bay oil fields and maps of numbers recorded did not reveal any evidence that density of birds was lower near developed areas. The USGS studied waterfowl using the lagoons in the vicinity of Prudhoe Bay (considered an industrial area) and in an undisturbed reference area adjacent to the Arctic National Wildlife Refuge (Flint and others, 2003; Lacroix and others, 2003; Flint and others, 2016). Those studies indicated that although flocks responded strongly to disturbance stimuli, there was no clear effect of open water seismic industrial activity and other disturbance on habitat use or foraging behaviors by molting long-tailed ducks (Clangula hyemalis). The study also indicated there was no effect of industrial development on nesting common eiders (Somateria mollissima) with the possible exception of increased nest predation risk for common eiders nesting near oil fields.

Liebezeit and others (2009) quantified nest survival of shorebird and passerine species in relation to areas with and without industrial development across the Arctic Coastal Plain. The authors also investigated the abundance and effect of subsidized predators (those benefiting from an association with human development) and non-subsidized predators on the nesting success of prey species. The authors observed substantial natural variation in annual nest survival across years and study locations, leading the authors to conclude that a development effect, if present, may be small relative to the natural annual variability in the Arctic. The authors found no effect of industry on nesting success for shorebirds (the most abundant guild of nesting birds on the Arctic Coastal Plain), but did observe a decline in nest survival of passerine species (the second most abundant group of birds nesting on the Arctic Coastal Plain) within $5 \mathrm{~km}$ of infrastructure. Although predation events were determined to be the primary cause of nest failure, the authors found that predator abundance was not related to nest survival and non-subsidized predators accounted for 32-77 percent of the total predators observed during surveys.

Meixell and Flint (2017) also examined predators and distance to industrial disturbance in relation to nesting behavior and success of greater white-fronted geese (Anser albifrons). Additionally, these authors quantified the effect of observer visits to nests. This study indicated only minor effects of industrial activity on goose nest attendance patterns and no measurable impact of low-flying helicopters on nest attendance patterns of geese. Nest survival was low for greater white-fronted geese nesting closer to industrial activity, but only in the first of the 2-year study when the number of arctic fox (Vulpes lagopus) visits to nests and fox depredation events were higher. This was likely because foxes used buildings as a base from which to hunt nesting birds and their eggs. In a year with lower fox activity, there was no difference in nest survival for nests close to and farther from industrial activity. Human foot traffic directly approaching nests had the greatest impact to nest attendance patterns and nest survival of greater white-fronted geese. Results for observer effects are consistent with findings from other studies on the central Arctic Coastal Plain involving king eiders (Somateria spectabilis; Bentzen and others, 2008) and loons (Uher-Koch and others, 2015). Meixell and Flint (2017) conclude that these results demonstrate a differential response by nesting geese to varying types of disturbance. Whereas observer visits were associated with direct human encroachment at nests that caused female geese to be absent from nests longer, sources of industrial disturbance in their study were characterized primarily by vehicular, aircraft, and foot travel that followed similar routes and usually did not directly approach nest sites. 
Bentzen and others (2017) used real and artificial shorebird and waterfowl nests located along roads in industrial areas of the central Arctic Coastal Plain to evaluate the relationship between distance from infrastructure and bird nesting success. The study indicated no effect from infrastructure on nest survival in either real or artificial nests. However, only 18 percent of artificial shorebird nests and 4 percent of artificial waterfowl nests survived the entire study. Since these rates appear to be biased low relative to real nests, the authors caution about conclusions derived from artificial nests regarding development impacts and nest predators.

\section{Permafrost}

Permafrost in the Beaufort Sea coastal area, including the 1002 Area, is continuous and active layer depth varies depending upon local conditions (Kanevskiy and others, 2013). Based on long-term (1977-2003) permafrost measurements, Osterkamp (2005) reported that the magnitude of total warming at the surface of the permafrost was $3-4{ }^{\circ} \mathrm{C}$ for the Arctic Coastal Plain. Kanevskiy and others (2013) surveyed permafrost characteristics across the Arctic Coastal Plain, including 16 sites within the 1002 Area. They identified four main land forms within the 1002 Area including (1) the primary surface, composed of predominantly gravelly sand, (2) the Yedoma, defined as extremely icerich Pleistocene permafrost with eolian silt, (3) river deltas and tidal flats, and (4) eolian dunes of sand. All of these land forms had high levels of volumetric ice ( $>73$ percent except for eolian sand which had 43 percent ice). The high ice content implies that these areas may be susceptible to subsidence associated with permafrost degradation. In areas of the NPR-A, Tape and others (2013) identified dramatic changes in vegetation characteristics apparently resulting from permafrost subsidence. As such, broad sections of the 1002 Area may see future changes in vegetation composition associated with permafrost degradation.

Jorgenson and others (2015a) found high variability and no significant trend in depth of the soil active layer above permafrost at their vegetation monitoring plots. Jorgenson and others (2015b) compiled a permafrost database to merge information on soil stratigraphy and laboratory data for 861 sites with boreholes, pits, and exposures where permafrost can be examined and monitored.

Farquharson and others (2016) examined the spatial distribution of thermokarst terrain in the western section of the Arctic Coastal Plain to determine which landscapes are most susceptible to thaw in the near future. The study determined that the coastal marine silts may be particularly susceptible to thaw, which has implications for ecosystem processes and human infrastructure near Utqiagivik and in the NPR-A. Similar information has not been developed for northeastern Alaska. Permafrost temperatures from deep boreholes spread across the western Arctic Coastal Plain indicate a trend of warming in the near surface, likely as a result of warmer winters with more snowfall and warmer summers (Clow, 2014). Borehole measurements on the coastal plain of the Arctic National Wildlife Refuge showed that permafrost temperatures increased between 1985 and 2004, at a similar rate to other North Slope sites (Osterkamp and Jorgenson, 2006).

\section{Coastal Erosion}

With the recent declines in sea ice in the Beaufort Sea, coastal erosion has become widespread and may be accelerating along the Arctic coast of Alaska, and is transforming some coastal habitats. Gibbs and Richmond $(2015,2017)$ examined shoreline change along Alaska's Arctic coast between 1947 and 2012 and found coastal erosion to be widespread and a threat to defense and energy-related infrastructure, coastal habitats, and Alaska Native communities. Gibbs and Richmond (2015, 2017) applied standard, repeatable methods for mapping and analyzing shoreline change so that periodic, systematic, and internally consistent updates regarding coastal erosion and land loss can be made nationally. Gibbs and Richmond (2017) determined that the northern coast of Alaska is dominantly erosional, with 84 percent of the total transects showing shoreline retreat over the long term (1940s- 
2010s) and 77 percent in the short term (1980s-2010s). The greatest average erosional rates were measured between Cape Halkett and the Ikpikpuk River Delta within the NPR-A. The greatest average erosional rates for regions in the 1002 Area (Canadian border to Hulahula River and Hulahula River to Staines River) were lower (approximately $-0.9 \mathrm{~m} / \mathrm{yr}$ ) than for areas in the NPR-A. According to Gibbs and Richmond (2015), observed and projected increases in periods of sea-ice free conditions suggest that Arctic coasts will be more vulnerable to storm surge and wave energy, potentially resulting in accelerated shoreline erosion and terrestrial habitat loss in the future.

\section{Coastal Lagoons}

Coastal lagoons of the southern Beaufort Sea support large numbers of fish and millions of migratory birds in the summer months. Dunton and others (2012) demonstrated a significant terrestrial carbon subsidy to the coastal lagoon ecosystem of the southern Beaufort Sea in northeastern Alaska. The authors found evidence for substantial energy transfer from terrestrial sources of carbon to zooplankton and benthic communities that in turn support higher trophic level organisms, such as waterfowl and fish, including Arctic cod. In 2017, a 5-year study began at a new Long-Term Ecological Research (LTER) site in northeastern Alaska along the Beaufort Sea coast that will focus on the ecological interactions between land and ocean in this region.

\section{Fish}

Arctic cisco (Coregonus autumnalis) and Dolly Varden (Salvelinus malma) are common fish species in coastal regions of northern Alaska. Freshwater habitats used by these and other fish species in the 1002 Area have been considered as potential water sources for future oil and gas development (Brown and others, 2014, and references therein). Brown (2008) quantified the long-term trends in demographic composition, relative abundance, and body condition of Arctic cisco and Dolly Varden in coastal lagoon systems of the 1002 Area near Barter Island during the years 1988-1991 and 20032005. Brown (2008) determined that abundance of mature-size Arctic cisco remained relatively stable between the early and late years of the study and that cisco encountered in the Barter Island region come from overwintering habitats in both the Colville and Mackenzie River deltas. Relative abundance of Dolly Varden remained stable across the study period. Additional information regarding other fish species is also discussed. Vivant (2009) provides aerial index counts of overwintering Dolly Varden from the Canning and Hulahula Rivers in 2007 and 2008. Counts varied substantially between years. For the Canning River, 3,936 and 7,533 fish were counted on the Canning River in 2007 and 2008, respectively. On the Hulahula River, 9,575 and 3,653 fish were seen in 2007 and 2008, respectively. Vivant cautions that these numbers should not be used to infer trends in abundance because of differences in survey methods, timing of fish migration, and annual variation.

Brown and others (2014) examined overwintering locations for Dolly Varden in perennial springs in rivers of the 1002 Area. Using radio transmitters, Brown and others (2014) found four discrete areas with perennial springs for overwintering Dolly Varden along the Hulahula River, with one of these occurring within the coastal plain of the 1002 Area. These four areas appear to represent all overwintering habitat in the Hulahula River drainage. Additionally, Brown and others (2014) determined that 20 percent of tagged fish moved to sites within the Canning, Aichilik, and Kongakut River drainages in subsequent years for overwintering. 
The U.S. Fish and Wildlife Service (2015) describes some of the 42 fish species found within the Arctic National Wildlife Refuge, not all of which occur in the 1002 Area. Thorsteinson and Love (2016) describe geographic distributions, life cycle schematics, and ecological information for 109 marine fish species of the Chukchi and Beaufort seas, including coastal and offshore regions of the 1002 Area. An on-going USGS research project is examining fish community composition in comparison to historical sampling in the 1980s and 1990s in the Beaufort Sea, including the coastal lagoons of the 1002 Area.

\section{Water Resources}

Understanding water resources in the 1002 Area informs questions related to multiple ecosystem components as well as possible infrastructure development. A USGS streamgage station was established October 1, 2010, on the Hulahula River (6942'41"N., 144 $11^{\circ} 24^{\prime \prime} \mathrm{W}$.) along a reach draining a $684 \mathrm{mi}^{2}$ watershed comprised of mountain, foothill, and coastal plain ecoregions. Air temperature, precipitation, and water levels are recorded and discharge is computed from a stagedischarge relationship. This is one of only five streamgages north of the Brooks Range, the only station within the Arctic National Wildlife Refuge, and the only site in the U.S. Arctic that measures streamflow from a glaciated watershed. More information is available at: https://waterdata.usgs.gov/ak/nwis/inventory/?site_no $=15980000$. Two additional USGS streamgages operated in the past. The Canning River station $\left(6 \overline{9}^{\circ} 52^{\prime} 55^{\prime \prime} \mathrm{N} ., 146^{\circ} 23^{\prime} 09^{\prime \prime} \mathrm{W}\right.$.) operated from June 23 , 2008, to September 29, 2012, and was located $338 \mathrm{ft}$ above mean sea level along a reach draining $1,930 \mathrm{mi}^{2}$ of the Brooks Range and foothills. The Tamayariak River station (69 $51^{\prime} 55^{\prime \prime} \mathrm{N}$., $145^{\circ} 35^{\prime} 34^{\prime \prime} \mathrm{W}$.) operated from June 1, 2008, to September 29, 2012, and was located $325 \mathrm{ft}$ above mean sea level along a reach draining $149 \mathrm{mi}^{2}$ of the coastal plain. The Canning River discharged the highest volume of water with annual mean flow ranging from 1,502 to 1,961 cubic feet per second $\left(\mathrm{ft}^{3} / \mathrm{s}\right)$ during the entire period of record. Annual mean flow on the Tamayariak ranged from 93.7 to $69.6 \mathrm{ft}^{3} / \mathrm{s}$ during the same period of record. Annual mean flow on the Hulahula River ranged from 489 to 745 $\mathrm{ft}^{3} / \mathrm{s}$ from 2010 to 2016 . The highest average monthly flows in the Canning and Tamayariak rivers occur during snowmelt in June. The highest average monthly flow in the glacier-fed Hulahula River, occurs during July.

\section{Acknowledgments}

We thank Beth Lenart (Alaska Department of Fish and Game), Jeff Conaway (U.S. Geological Survey [USGS]), Ann Gibbs (USGS), Brad Griffith (USGS), Jerry Hupp (USGS), Sarah Thompson (USGS), Vanessa Von Biela (USGS), John Buursma (USGS), Patrick Lemons (U.S. Fish and Wildlife Service [USFWS]), Greta Burkhart (USFWS), Roy Churchwell (USFWS), Janet Jorgenson (USFWS), Dave Payer (USFWS), Ted Swem (USFWS), Steve Kendall (USFWS), and Rick Lanctot (USFWS) for their reviews of this report. Mary Whalen (USGS) assisted with all figures. 


\section{References Cited}

Afema, J.A., Beckmen, K.B., Arthur, S.M., Burek Huntington, K., and Mazet, J.A.K., 2017, Disease complexity in a declining Alaskan muskox (Ovibos moschatus) population: Journal of Wildlife Diseases, v. 53, p. 311-329.

Alaska Department of Fish and Game, 2018, Porcupine caribou herd grows to record numbers: Alaska Department of Fish and Game Web page, Press Release, January 2, 2018, accessed January 9, 2018, at http://www.adfg.alaska.gov/index.cfm?adfg=pressreleases.pr\&release=2018_01_02.

Arthur, S.M., and Del Vecchio, P.A., 2009, Effects of oil field development on calf production and survival in the Central Arctic herd: Juneau, Alaska, Alaska Department of Fish and Game, Federal Aid in Wildlife Restoration, Final Research Technical Report, Grants W-27-5 and W-33-1 through W-33-4, Project 3.46, accessed December 26, 2017, at http://www.adfg.alaska.gov/index.cfm?adfg=librarypublications.wildlifepublicationsdetails\&pubide ntifier $=48$.

Arthur, S.M., and Del Vecchio, P.A., 2013, Population dynamics of muskoxen in northeastern Alaska: Juneau, Alaska, Alaska Department of Fish and Game, Final Wildlife Research Report ADF\&/DWC/WRR-2013-1, Project 16.10, accessed November 27, 2017, at https://www.adfg.alaska.gov/static/home/library/pdfs/wildlife/research_pdfs/wrr_2013_1.pdf.

Arthur, S.M., and Del Vecchio, P.A., 2017, Effects of grizzly bear predation on muskoxen in northeastern Alaska: Ursus, v. 28, p. 81-91.

Atwood, T.C., Peacock, E., McKinney, M., Douglas, D.C., Lillie, K., Wilson, R.R., Terletzky, P., and Miller, S., 2016, Rapid environmental change drives increased land use by an Arctic marine predator: PLoS One, v. 11, p. e0155932.

Bart, J., Platte, R.M., Andres, B.A., Brown, S., Johnson, J.A., and Larned, W., 2013, Importance of the National Petroleum Reserve-Alaska for aquatic birds: Conservation Biology, v. 27, p. 1,304-1,312.

Bentzen, R.L., Powell, A.N., and Suydam, R.S., 2008, Factors influencing nesting success of king eiders on northern Alaska's coastal plain: Journal of Wildlife Management, v. 72, p 1,781-1,789.

Bentzen, R.L., Dinsmore, S., Liebezeit, J., Robards, M., Streever, B., and Zack, S., 2017, Assessing development impacts on Arctic nesting birds using real and artificial nests: Polar Biology, v. 40, p. 1,527-1,536.

Boggs, K., Flagstad, L.V., Boucher, T., Kuo, T., Fehringer, D., Guyer, S., and Aisu, M., 2016, Vegetation map and classification-Northern, Western and Interior Alaska: Anchorage, Alaska, Alaska Natural Heritage Program, Alaska Center for Conservation Science, University of Alaska Anchorage, accessed November 27, 2017, at http://accs.uaa.alaska.edu/files/vegetationecology/VegetationMap_NorthernWesternInteriorAlaska_UserGuide.pdf.

Bromaghin, J.F., McDonald, T.L., Stirling, I., Derocher, A.E., Richardson, E.S., Regehr, E.V., Douglas, D.C., Durner, G.M., Atwood, T.C., and Amstrup, S.C., 2015, Polar bear population dynamics in the southern Beaufort Sea during a period of sea ice decline: Ecological Applications, $v$. 25, p. 634-651.

Brown, R.J., 2008, Life history and demographic characteristics of Arctic Cisco, Dolly Varden, and other fish species in the Barter Island region of Northern Alaska: U.S. Fish and Wildlife Service, Anchorage, Alaska, Alaska Fisheries Technical Report Number 101, 52 p., accessed December 26, 2017, at https://www.fws.gov/alaska/fisheries/fish/Technical_Reports/t_2008_101.pdf.

Brown, R.J., Loewen, M.B., and Tanner, T.L., 2014, Overwintering locations, migrations, and fidelity of radio-tagged Dolly Varden in the Hulahula River, Arctic National Wildlife Refuge, 2007-09: Arctic, v. 67, p. 149-158.

Brown, S., Bart, J., Lanctot, R.B., Johnson, J.A., Kendall, S., Payer, D., and Johnson, J., 2007, Shorebird abundance and distribution on the coastal plain of the Arctic National Wildlife Refuge: The Condor, v. 109, p. 1-14. 
Brown, S., Kendall, S., Churchwell, R., Taylor, A., and Benson, A-M., 2012, Relative shorebird densities at coastal sites in the Arctic National Wildlife Refuge: Waterbirds, v. 35, p. 546-554.

Burgess, R.M., Ritchie, R.J., Person, B.T., Suydam, R.S., Shook, J.E., Pritchar, A.K., and Obritschkewitsch, T., 2017, Rapid growth of a nesting colony of lesser snow geese (Chen caerulescens caerulescens) on the Ikpikpuk River Delta, North Slope, Alaska, USA: Waterbirds, v. 40, p. 11-23.

Caikoski, J.R., 2015, Units 25A, 25B, 25D, and 26C caribou, chap. 15, in Harper P., and McCarthy, L.A., eds., Caribou management report of survey and inventory activities 1 July 2012-30 June 2014: Juneau, Alaska, Alaska Department of Fish and Game, Species Management Report ADF\&G/DWC/SMR-2015-4, p. 15-1-15-24, accessed December 26, 2017, at http://www.adfg.alaska.gov/index.cfm?adfg=librarypublications.wildlifepublicationsdetails\&pubide ntifier $=1876$.

Cameron, R.D., Reed, D.J., Dau, J.R., and Smith, W.T., 1992, Redistribution of calving caribou in response to oil field development on the arctic slope of Alaska: Arctic, v. 45, p. 338-342.

Cameron, R.D., Lenart, E.A., Reed, D.J., Whitten, K.R., and Smith, W.T., 1995, Abundance and movements of caribou in the oilfield complex near Prudhoe Bay, Alaska: Rangifer, v. 15, p. 3-7.

Chapin, F.S., III, Trainor, S.F., Cochran, P., Huntington, H., Markon, C., McCammon, M., McGuire, A.D., Serreze, M., 2014, Alaska-Climate Change Impacts in the United States, chap. 22, in Melillo, J.M., Richmond, T.C., and Yohe, G.W., eds., The Third National Climate Assessment: U.S. Global Change Research Program, p. 514-536, accessed December 26, 2017, at http://doi.org/10.7930/J00Z7150.

Chesser, R.T, Burns, K.J., Cicero, C., Dunn, J.L., Kratter, A.W., Lovette, I.J., Rasmussen, P.C., Remsen, Jr., J.V., Rising, J.D., Stotz, D.F., and Winker, K., 2017, Fifty-eighth supplement to the American Ornithologists' Union Check-list of North American Birds: The Auk, v. 134, p. 751-773.

Churchwell, R.T., Kendall, S.J., Blanchard, A.L., Dunton, K.H., and Powell, A.N., 2016, Natural disturbance shapes benthic intertidal macroinvertebrate communities of high latitude river deltas: Estuaries and Coasts, v. 39, no. 3, p. 798-814.

Churchwell, R.T., Kendall, S.J., Brown, S.C., Blanchard, A.L., Hollmen, T.E., Powell, A.N., 2017, The first hop: use of Beaufort Sea deltas by hatch-year semipalmated sandpipers. Estuaries and Coasts, v. 41, no. 1, p. 280-292.

Clough, N.K., Patton, P.C., and Christiansen, A.C., eds., 1987, Arctic National Wildlife Refuge, Alaska, coastal plain resource assessment-Report and recommendation to the Congress of the United States and final legislative environmental impact statement: Washington, D.C., U.S. Fish and Wildlife Service, U.S. Geological Survey, and Bureau of Land Management, v. 1, 208 p, accessed January 9, 2018, at https://pubs.er.usgs.gov/publication/70039559.

Clow, G., 2014, Temperature data acquired from the DOI/GTN-P Deep Borehole Array on the Arctic Slope of Alaska, 1973-2013: Earth System Science Data, v. 6, p. 201-218.

Dau, C.P., and Bollinger, K.S., 2009, Aerial population survey of common eiders and other waterbirds in nearshore waters and along barrier islands of the Arctic Coastal Plain of Alaska, 1-5 July 2009, 20 p., accessed November 27, 2017, at https://www.fws.gov/alaska/mbsp/mbm/waterfowl/reports.htm.

Douglas, D.C., Reynolds, P.E., and Rhode, E.B., 2002, Arctic Refuge coastal plain terrestrial wildlife research summaries, USGS Biological Science Report 2002-0001, 76 p., accessed December 26, 2017, at https://alaska.usgs.gov/products/pubs/2002/2002-USGS-BRD-BSR-2002-0001.pdf.

Dunton, K.H., Schonberg, S.V., and Cooper, L.W., 2012, Food web structure of the Alaskan nearshore shelf and estuarine lagoons of the Beaufort Sea: Estuaries and Coasts, v. 35, p. 416-435.

Durner, G.M., Amstrup, S.C., and Ambrosius, K.J., 2006, Polar bear maternal den habitat on the Arctic National Wildlife Refuge, Alaska: Arctic, v. 59, no. 1, p. 31-36. 
Durner, G.M., Fischbach, A.S., Amstrup, S.C., and Douglas, D.C., 2010, Catalogue of polar bear (Ursus maritimus) maternal den locations in the Beaufort Sea and neighboring regions, Alaska, 1910-2010: U.S. Geological Survey Data Series 568, 14 p., https://pubs.usgs.gov/ds/568/.

Farquharson, L.M., Mann, D.H., Grosse, G., Jones, B.M., and Romanovsky, V.E., 2016, Spatial distribution of thermokarst terrain in Arctic Alaska: Geomorphology, v. 275, p. 116-133.

Flint, P.L., Reed, J.A., Franson, J.C., Hollmén, T.E., Grand, J.B., Howell, M.D., Lanctot, R.B., Lacroix, D.L., and Dau, C.P., 2003, Monitoring Beaufort Sea waterfowl and marine birds: Anchorage, Alaska, U.S. Geological Survey, Alaska Science Center, OCS Study MMS 2003-037, 125 p., accessed December 26, 2017, at https://www.boem.gov/ESPIS/3/3355.pdf.

Flint, P.L., Reed, J.A., Lacroix, D.L., and Lanctot, R.B., 2016, Habitat use and foraging patterns of molting long-tailed ducks in lagoons of the central Beaufort Sea, Alaska: Arctic, v. 69, no. 1, p. 1928.

Garner, G.W., and Reynolds, P.E., eds., 1986, Arctic National Wildlife Refuge coastal plain resource assessment-Final report baseline study of the fish, wildlife, and their habitats: Anchorage, Alaska, U.S. Department of the Interior, U.S. Fish and Wildlife Service, Region 7, December 1986, v. 1, 425, accessed December 26, 2017, at https://data.doi.gov/dataset/final-report-baseline-study-of-thefish-wildlife-and-their-habitats/resource/289d09d5-74fa-441b-9cf2-33489d197e2b.

Garner, G.W., and Reynolds, P.E., eds., 1987, Arctic National Wildlife Refuge coastal plain resource assessment - 1985 Update Report, Baseline Study of the Fish, Wildlife, and Their Habitats: Anchorage, Alaska, U.S. Department of the Interior, U.S. Fish and Wildlife Service, Region 7, December 1986, v. 1, p. 255-324.

Gibbs, A.E., and Richmond, B.M., 2015, National assessment of shoreline change-Historical shoreline change along the north coast of Alaska, U.S.-Canadian border to Icy Cape: U.S. Geological Survey Open-File Report 2015-1048, 96 p., accessed December 26, 2017 at https://doi.org/10.3133/ofr20151048.

Gibbs, A.E., and Richmond, B.M., 2017, National assessment of shoreline change-Summary statistics for updated vector shorelines and associated shoreline change data for the north coast of Alaska, U.S.-Canadian border to Icy Cape: U.S. Geological Survey Open-File Report 2015-1048, 21 p., accessed December 26, 2017 at https://pubs.er.usgs.gov/publication/ofr20171107.

Griffith, B.G., Douglas, D.C., Walsh, N.E., Young, D.D., McCabe, T.R., Russell, D.E., White, R.G., Cameron, R.D., and Whitten, K.R., 2002, Section 3-The Porcupine Caribou Herd, in Douglas, D.C., Reynolds, P.E., and Rhode, E.B., eds., Arctic Refuge coastal plain terrestrial wildlife research summaries: USGS Biological Science Report 2002-0001, p. 8-37, accessed December 26, 2017, at: https://alaska.usgs.gov/products/pubs/2002/2002-USGS-BRD-BSR-2002-0001.pdf.

Gustine, D.D., Barboza, P.S., Adams, L.G., Griffith, B., Cameron, R.D., and Whitten, K.R., 2017 , Advancing the match-mismatch framework for large herbivores in the Arctic-Evaluating the evidence for a trophic mismatch in caribou: PLoS One, v. 12, p. e0171807.

Harper, P., and McCarthy, L.A., eds., 2015, Caribou management report of survey-inventory activities 1 July 2012-30 June 2014: Alaska Department of Fish and Game, Species Management Report, ADF\&G/DWC/SMR-2015-4, accessed November 27, 2017, at http://www.adfg.alaska.gov/index.cfm?adfg=wildliferesearch.smr20154.

Haskell, S.P., Nielson, R.M., Ballard, W.B., Cronin, M.A., and McDonald, T.L., 2006, Dynamic responses of calving caribou to oilfields in Northern Alaska: Arctic, v. 59, p. 179-190.

Hinzman, L.D., Bettez, N.D., Bolton, W.R., and others, 2005, Evidence and implications of recent climate change in northern Alaska and other Arctic regions: Climate Change, v. 72, p. 251-298.

Holland-Bartels, Leslie, and Pierce, Brenda, eds., 2011, An evaluation of the science needs to inform decisions on Outer Continental Shelf energy development in the Chukchi and Beaufort Seas, Alaska: U.S. Geological Survey Circular 1370, 278 p., accessed January 6, 2018, at https://pubs.usgs.gov/circ/1370/. 
Hupp, J.W., Robertson, D.G., and Brackney, A.W., 2002, Section 9-Snow geese, in Douglas, D.C., Reynolds, P.E., and Rhode, E.B., eds., Arctic Refuge coastal plain terrestrial wildlife research summaries: USGS Biological Science Report 2002-0001, p. 71-74, accessed January 2, 2018, at: https://alaska.usgs.gov/products/pubs/2002/2002-USGS-BRD-BSR-2002-0001.pdf.

Hupp, J.W., Ward, D.H., Hogrefe, K.R., Sedinger, J.G., Martin, P.D., Stickney, A., and Obritschkewitsch, T., 2017, Growth of black brant and snow goose goslings in northern AlaskaImplications for increasing goose populations: Journal of Wildlife Management, v. 81, no. 5, p. 846857.

Intergovernmental Panel on Climate Change [IPCC], 2014, Climate Change 2014-Synthesis Report: Geneva, Switzerland, Contribution of Working Groups I, II and III to the Fifth Assessment Report of the Intergovernmental Panel on Climate Change, Core Writing Team, R.K. Pachauri and L.A. Meyer, eds., IPCC, $151 \mathrm{p}$.

Johnson, J.A., Lanctot, R.B., Andres, B.A., Bart, J.R., Brown, S.C., Kendall, S.J., and Payer, D.C., 2007, Distribution of breeding shorebirds on the Arctic Coastal Plain of Alaska: Arctic, v. 60, p. 277-293.

Johnson, C.J., and Russell, D.E., 2014, Long-term distribution responses of a migratory caribou herd to human disturbance: Biological Conservation, v. 177, p. 52-63.

Joly, K., Nellemann, C., and Vistnes, I., 2006, A reevaluation of caribou distribution near an oilfield road on Alaska's North Slope: Wildlife Society Bulletin, v. 34, p. 866-869.

Jorgenson, J.C., Joria, P.C., Doulas, D.C., 2002, Land Cover, in Douglas, D.C., Reynolds, P.E., and Rhode, E.B., eds., 2002, Arctic Refuge coastal plain terrestrial wildlife research summaries: U.S. Geological Survey Biological Science Report 2002-0001, p. 4-7, accessed January 2, 2018, at: https://alaska.usgs.gov/products/pubs/2002/2002-USGS-BRD-BSR-2002-0001.pdf.

Jorgenson, J.C., Raynolds, M.K., Reynolds, J.H., and Benson, A-M., 2015a, Twenty-five year record of changes in plant cover on tundra of northeastern Alaska: Arctic, Antarctic, and Alpine Research, v. 47, p. 785-806.

Jorgenson, M.T., and Heiner, M., 2003, Ecosystems of northern Alaska: 1:2.5 million-scale map produced by ABR, Inc., Fairbanks, Alaska, and The Nature Conservancy, Anchorage, Alaska, accessed December 26, 2017, at http://alaska.glynx.gina.alaska.edu/catalog/entries/5499ecosystems-of-northern-alaska-jorgenson-hein.

Jorgenson, M.T., and Grunblatt, J., 2013, Landscape-level ecological mapping of northern Alaska and field site photography report: Final report to the Arctic Landscape Conservation Cooperative, 4 March 2013, 45 p., accessed November 27, 2017, at http://arcticlcc.org/projects/geospatialdata/ecological-mapping-and-field-plot-database/.

Jorgenson, M.T., Kanevskiy, M., Shur, Y., Grunblatt, H., Ping, C-L., and Michaelson, G., 2015b, Permafrost database development, characterization, and mapping for northeastern Alaska:

Anchorage, Alaska, U.S. Fish and Wildlife Service, Final Report, 46 p., accessed November 27, 2017, at http://arcticlcc.org/projects/ALCC2012-10.

Kanevskiy, M., Shur, Y., Jorgenson, M.T., Ping, C-L., Michaelson, G.J., Fortier, D., Stephani, E., Dillon, M., and Tumskoy, V., 2012, Ground ice in the upper permafrost on the Beaufort Sea coast of Alaska: Cold Regions Science and Technology, v. 85, p. 56-70.

Kendall, S., 2005, Surveys of breeding birds on barrier islands in the Arctic National Wildlife Refuge, 2003-2004, 48 p., accessed December 26, 2017, at https://catalog.data.gov/dataset/surveys-ofbreeding-birds-on-barrier-islands-in-the-arctic-national-wildlife-refuge.

Lacroix, D.L., Lanctot, R.B., Reed, J.A., and McDonald, T.L., 2003, Effect of underwater seismic surveys on molting male long-tailed ducks in the Beaufort Sea, Alaska: Canadian Journal of Zoology, v. 81, p. 1,862-1,875. 
Leibezeit, J.R, Kendall, S.J., Brown, S., Johnson, C.B., Martin, P., McDonald, T.L., Payer, D.C., Rea, C.L., Streever, B., Wildman, A.M., and Zack, S., 2009, Influence of human development and predators on nest survival of tundra birds, Arctic Coastal Plain, Alaska: Ecological Applications, v. 19 , p. 1,628-1,644.

Lysne, L.A., Mallek, E.J., and Dau, C.P., 2004, Near shore surveys of Alaska's Arctic coast, 19992003: U.S. Fish and Wildlife Service, Migratory Bird Management, Waterfowl Branch report, Fairbanks, Alaska, accessed January 8, 2018, at https://www.fws.gov/alaska/mbsp/mbm/waterfowl/surveys/pdf/NSSANC.pdf.

Marcot, B.G., Jorgenson, M.T., Lawler, J.P., Handel, C.M., and DeGange, A.R., 2015, Projected changes in wildlife habitats in Arctic natural areas of northwest Alaska: Climatic Change, v. 130, p. 145-154.

McFarland, H.R., Caikoski, J., Lenart, E., and Taras, M., 2017, Porcupine caribou news: Fairbanks, Alaska, Alaska Department of Fish and Game, Division of Wildlife Conservation, [Newsletter], accessed November 27, 2017, at:

http://www.adfg.alaska.gov/static/home/library/pdfs/wildlife/porcupine_caribou_news/porcupine_ca ribou_news_summer_2017.pdf.

McKinney, M., Atwood, T.C., Iverson, S.J., and Peacock, E., 2017, Onshore food subsidies add complexity to the response of Alaska polar bears to climate change: Ecosphere, v. 8, p. e0.633, doi:10.1002/ecs2.1633.

Meixell, B.W., and Flint, P.L., 2017, Effects of industrial and investigator disturbance on Arcticnesting geese: Journal of Wildlife Management, v. 81, p. 1,372-1,385.

Miller, J.H., Druckenmiller, P., and Bahn, V., 2013, Antlers on the Arctic Refuge: capturing multigenerational patterns of calving ground use from bones on the landscape: Proceedings of the Royal Society B, 280, 20130275.

Miller, M.W., Jensen, K.C., Grant, W.E., and Weller, M.W., 1994, A simulation model of helicopter disturbance of molting Pacific Black Brant: Ecological Modeling, v. 73, p. 293-309.

Nellemann, C., and Cameron, R.D., 1998, Cumulative impacts of an evolving oil-field complex on the distribution of calving caribou: Canadian Journal of Zoology, v. 76, p. 1,425-1,430.

Nellemann, C., Vistnes, I., Jordhøy, P., Strand, O., and Newton, A., 2003, Progressive impact of piecemeal infrastructure development on wild reindeer: Biological Conservation, v. 113, p. 307-317.

Nicholson, K.L., Arthur, S.M., Horne, J.S., Garton, E.O., and Del Vechhio, P.A., 2016, Modeling caribou movements - Seasonal ranges and migration routes of the Central Arctic herd: PLoS One, v. 11, p. e0150333.

Olson, J.W., Rode, K.D., Smith, T.S., Wilson, R.R., Durner, G.M., Fischbach, A., Atwood, T.C., and Douglas, D.C., 2017, Collar temperature sensor data reveal long-term patterns in southern Beaufort Sea polar bear den distribution on pack ice and land: Marine Ecology Progress Series, v. 564, p. 211-224.

Osterkamp, T.E., 2005, The recent warming of permafrost in Alaska: Global and Planetary Change, v. 49, p. 187-202.

Osterkamp, T.E., and Jorgenson, J.C., 2006, Warming of permafrost in the Arctic National Wildlife Refuge, Alaska: Permafrost and Periglacial Processes, v. 17, p. 65-69.

Pacific Flyway Council, 2013, Pacific Flyway management plan for the western Arctic population of Lesser Snow Geese: Portland, Oregon, Pacific Flyway Council [c/o U.S. Fish and Wildlife Service, DMBM, Portland, Oregon], 37 p., accessed December 26, 2017, at http://www.pacificflyway.gov/Documents/Walsg_plan.pdf.

Pollard, R.H., Ballard, W.B., Noel, L.E., and Cronin, M.A., 1996, Summer distribution of caribou, Rangifer tarandus granti, in the area of the Prudhoe Bay oil field, Alaska, 1990-1994: Canadian Field Naturalist, v. 110, p. 659-674. 
Raynolds, M.K., Breen, A.L., and Walker, D.A., 2017, Pre-ABoVE_-Land cover and ecosystem map collection for northern Alaska: Oak Ridge, Tennessee, ORNL DAAC, accessed January 17, 2018, at https://doi.org/10.3334/ORNLDAAC/1359.

Reed, J., and Duplisea, D., 2017, Guided recreational polar bear viewing 2015-2016 summary report: Fairbanks, Alaska, Arctic National Wildlife Refuge, 15 p., accessed November 27, 2017, at https://www.fws.gov/uploadedFiles/Region_7/NWRS/Zone_1/Arctic/PDF/201516\%20PBV\%20Summary\%20Report.pdf.

Rode, K.D., Olson, J., Eggett, D., Douglas, D.C., Durner, G.M., Atwood, T.C., Regehr, E.V., Wilson, R.R., Smith, T., and St. Martin, M., 2018, Den phenology and reproductive success of polar bears in a changing climate: Journal of Mammalogy, gyx181, accessed January 17, 2018, at https://doi.org/10.1093/jmammal/gyx 181 .

Rogers, M.C., Peacock, E., Simac, K., O’Dell, M.B., and Welker, J.M., 2015, Diet of female polar bears in the southern Beaufort Sea of Alaska-Evidence for an emerging alternative foraging strategy in response to environmental change: Polar Biology, v. 38, p. 1,035-1,047.

Saalfeld, S.T., Lanctot, R.B., Brown, S.C., Saalfeld, D.T., Johnson, J.A., Andres, B.A., and Bart, J.R., 2013a, Predicting breeding shorebird distributions on the Arctic Coastal Plain of Alaska: Ecosphere, v. 4, p. 16. doi:10.1890/ES12-00292.1.

Saalfeld, S.T., Hill, B.L., and Lanctot, R.B., 2013b, Shorebird responses to construction and operation of a landfill on the Arctic Coastal Plain: The Condor, v. 115, p. 816-829.

Stehn, R., and Platte, R., 2009, Steller's eider distribution, abundance, and trend on the Arctic Coastal Plain, Alaska, 1989-2008: U.S. Fish and Wildlife Service report, 35 p., accessed December 4, 2017, at http://www.fws.gov/alaska/mbsp/mbm/waterfowl/surveys/pdf/

Stehn_Platte\%202009\%20STEI\%20distribution_trend\%20Alaska.pdf.

Stehn, R., Larned, W.W., and Platte, R.M., 2013, Analysis of aerial survey indices monitoring waterbird populations of the Arctic Coastal Plain, 1986-2012: U.S. Fish and Wildlife Service, Migratory Bird Management, 56 p., accessed December 4, 2017, at https://www.fws.gov/alaska/mbsp/mbm/waterfowl/surveys/acpbp.htm.

Stern, H.L., and Laidre, K.L, 2016, Sea ice indicators of polar bear habitat: The Cryosphere, v. 10, p. $2,027-2,041$.

Stroeve, J.C., Markus, T., Boisvert, L., Miller, J., and Barrett, A., 2014, Changes in Arctic melt season and implications for sea ice loss: Geophysical Research Letters, v. 41, p. 1216-1225.

Schliebe, S., Rode, K.D., Gleason, J.S., Wilder, J., Proffitt, K., Evans, T.J., and Miller, S., 2008, Effects of sea ice extent and food availability on spatial and temporal distribution of polar bears during the fall open-water period in the Southern Beaufort Sea: Polar Biology, v. 31, p. 999-1,010.

Smith, W.T., and Cameron, R.D., 1985, Reactions of large groups of caribou to a pipeline corridor on the arctic coastal plain of Alaska: Arctic, v. 38, p. 53-57.

Stern, H.L. and Laidre, K.L, 2016, Sea ice indicators of polar bear habitat: The Cryosphere, v. 10, p. 2,027-2,041.

Stroeve, J.C., Markus, T., Boisvert, L., Miller, J., and Barrett, A., 2014, Changes in Arctic melt season and implications for sea ice loss: Geophysical Research Letters, v. 41, p. 1,216-1,225.

Tape, K.D., Flint, P.L., Meixell, B.W., and Gaglioti, B.V., 2013, Inundation, sedimentation, and subsidence creates goose habitat along the Arctic Coast of Alaska: Environmental Research Letters, v. 8, p. 045031.

Taras, M.E., and McFarland, H., eds., 2016, Central Arctic caribou herd news, winter 2016-17: Fairbanks, Alaska, Alaska Department of Fish and Game, Division of Wildlife Conservation, [Newsletter], accessed November 27, 2017, at http://www.adfg.alaska.gov/index.cfm?adfg=librarypublications.wildlifepublicationsdetails\&pubide ntifier $=3256$. 
Taylor, A.R., Lanctot, R.B., Powell, A.N., Huettman, F., Nigro, D.A., and Kendall, S.J., 2010, Distribution and community characteristics of staging shorebirds on the northern coast of Alaska: Arctic, v. 63, p. 451-467.

Taylor, A.R., Lanctot, R.B., Powell, A.N., Kendall, S.J., and Nigro, D.A., 2011, Residence time and movements of postbreeding shorebirds on the northern coast of Alaska: The Condor, v. 114, p. 779794.

Thorsteinson, L.K., and Love, M.S., eds., 2016, Alaska Arctic marine fish ecology catalog: U.S. Geological Survey Scientific Investigations Report 2016-5038 (OCS Study, BOEM 2016-048), 768 p., accessed January 5, 2018, at http://dx.doi.org/10.3133/sir20165038.

Uher-Koch, B.D., Schmutz, J.A., and Wright, K.G., 2015, Nest visits and capture events affect breeding success of yellow-billed and Pacific loons: The Condor, v. 117, p. 121-129.

Urban, F.E., and Clow, G.D., 2017, DOI/GTN-P Climate and active-layer data acquired in the National Petroleum Reserve-Alaska and the Arctic National Wildlife Refuge, 1998-2015: U.S. Geological Survey Data Series 1021, 546 p., accessed January 6, 2018, at https://doi.org/10.3133/ds1021.

U.S. Fish and Wildlife Service, 2015b, Arctic National Wildlife Refuge revised comprehensive conservation plan-Appendix F, species list: U.S. Fish and Wildlife Service, Final environmental impact statement, v. 2, 42 p., accessed November 27, 2017, at https://www.fws.gov/home/arctic$\operatorname{ccp} /$.

U.S. Fish and Wildlife Service, 2015a, Arctic National Wildlife Refuge revised comprehensive conservation plan - Chapter 4, Affected Environment: U.S. Fish and Wildlife Service, Final environmental impact statement, v. 1, 256 p., accessed November 27, 2017, at https://www.fws.gov/home/arctic-ccp/.

Van Hemert, C.R., Flint, P.L., Udevitz, M.S., Koch, J.C., Atwood, T.C., Oakley, K.L., and Pearce, J.M., 2015, Forecasting wildlife response to rapid warming in the Alaskan Arctic: BioScience v. 65, p. 718-728, doi:10.1093/biosci/biv069.

Viavant, T., 2009, Aerial monitoring of Dolly Varden overwintering abundance in the Anaktuvuk, Ivishak, Canning, and Hulahula rivers, 2006-2008: Anchorage, Alaska, Alaska Department of Fish and Game, Fishery Data Series No. 09-21, accessed December 26, 2017, at http://www.adfg.alaska.gov/fedaidpdfs/FDS09-21.pdf.

Wilson, R.R., Prichard, A.K., Parrett, L.S., Person, B.T., Carroll, G.M., Smith, M.A., Rea, C.L., and Yokel, D.A., 2012, Summer resource selection and identification of important habitat prior to industrial development for the Teshekpuk Caribou Herd in northern Alaska: PLoS ONE, v. 7, p. e48697.

Wilson, R., Regehr, E., St. Martin, M., Atwood, T.C., Peacock, E., Miller, S., and Divoky, G., 2017, Relative influences of climate change and human activity on the onshore distribution of polar bears: Biological Conservation, v. 214, p. 288-294. 

Publishing support provided by the U.S. Geological Survey Science Publishing Network, Tacoma Publishing Service Center

For more information concerning the research in this report, contact the Director, Alaska Science Center

U.S. Geological Survey

4230 University Drive

Anchorage, Alaska 99508

https://alaska.usgs.gov 
